\title{
Near-Surface Geochemical Anomalies Integrated with Seismic and Well Data over the Contact of the Outer Carpathians and the Carpathian Foredeep (SE Poland)
}

\author{
Henryk Sechman (D), Adrianna Góra, Anna Twaróg, Piotr Guzy, Ewelina Górska-Mruk, \\ and Wojciech Górecki
}

Faculty of Geology, Geophysics and Environmental Protection, AGH University of Science and Technology, al. A. Mickiewicza 30, 30-059 Krakow, Poland

Correspondence should be addressed to Henryk Sechman; sechman@agh.edu.pl

Received 28 February 2018; Accepted 15 May 2018; Published 14 June 2018

Academic Editor: Julie K. Pearce

Copyright (c) 2018 Henryk Sechman et al. This is an open access article distributed under the Creative Commons Attribution License, which permits unrestricted use, distribution, and reproduction in any medium, provided the original work is properly cited.

\begin{abstract}
The objective of this study is to interpret the regularities in distribution of surface geochemical anomalies observed in a fragment of the contact zone between the Carpathian Fold-and-Thrust Belt and the Carpathian Foredeep (SE Poland). The surface geochemical survey included a total of 670 soil gas samples analyzed by gas chromatography, integrated with seismic cross sections, and supplemented by production data from wells. Maximum concentrations of methane, total alkanes $\mathrm{C}_{2}-\mathrm{C}_{5}$, total alkenes $\mathrm{C}_{2}-\mathrm{C}_{4}$, $\mathrm{H}_{2}$, and $\mathrm{CO}_{2}$ measured in soil gas samples were $27.1 \mathrm{vol} . \%, 45.3 \mathrm{ppm}, 0.49 \mathrm{ppm}, 0.232 \mathrm{vol} . \%$, and 6.29 vol.\%, respectively. Traces of alkanes detected in samples are the result of microseepage from a few accumulations of various compositions. Methane and ethane migrate primarily from relative shallow Miocene strata, and higher alkanes from deeper Miocene strata and from Paleozoic-Mesozoic basement. We found relatively high positive correlation between the distribution of surface geochemical anomalies and the relative intensity of hydrocarbon shows recorded in the wells. The location and range of 13 anomalous zones are controlled by the patterns of both the Dębno and the Wojnicz slice-folds. Most of the anomalies occur over the Wojnicz Trough, suggesting the presence of conventional accumulations and/or the sites where the Miocene mudstone and heterolithic formations are saturated with gas.
\end{abstract}

\section{Introduction}

In the Polish part of the Carpathian Foredeep, 84 gas and 6 oil deposits have been discovered up to the present [1]. The gas deposits are most common in the Miocene formations whereas the oil ones occur in the Paleozoic-Mesozoic basement of the Miocene succession. These hydrocarbon accumulations were discovered and assessed using the data from the seismic survey, particularly the interpretation of direct hydrocarbon indicators in seismic sections, which gave rise to the identification of anomalous seismic records resulted from saturation of sandstone horizons with gas $[2,3]$. However, both the studies and the interpretation of seismic anomalies deadly need the high-quality seismic data. It is not surprising that all the petroleum deposits discovered with the direct hydrocarbon indicators are located outside the Carpathian Overthrust $[2,3]$. In the contact zone of the Carpathian Fold-and-Thrust Belt with the Carpathian Foredeep, the readability of seismic records is limited [4], which practically precludes the identification of anomalous seismic zones. Hence, the integration of seismic and surface geochemical data may be instrumental in the localization of hydrocarbon accumulations.

The surface geochemical survey applied to the exploration of deep hydrocarbon accumulations is based upon the premise that both the concentration and the pressure gradients enable the seepage of hydrocarbons from accumulating into the enclosing rock formations. Generally, it is valid for 
light gaseous hydrocarbons, which primarily migrate, vertically, first due to diffusion and then (if conditions allow) also by effusion towards the Earth's surface and finally become dispersed in the Earth's atmosphere [4-7]. Apart from diffusional/effusional migration from deep accumulations to the surface, some other mechanisms of secondary vertical hydrocarbon migration are quoted, for example, hydrodynamic migration in water solutions and colloids $[8,9]$. Other migration mechanism can be the hydrostatic lift of microbubbles of light gaseous hydrocarbons, which drives their episodic seepage towards the surface along the systems of fissures and microfractures or through the tectonic zones cutting the caprocks of hydrocarbon accumulations [8, 10-12]. Recent studies carried on in the Carpathian Foredeep [13] demonstrated that such migration can be recorded in the seismic sections as so-called "gas chimneys." One chimney was confirmed by surface geochemical survey by Marzec et al. [13]. Chimneys may play a key role in gas saturation of Miocene heterolithic successions composed of thin, isolated, commonly poorly lithified sandstone/mudstone alternations [14-16].

The gas accumulations in Miocene reservoirs are dominated by methane of microbial provenance generated primarily by reduction of carbon dioxide $[17,18]$. In addition to methane, ethane and propane are also present, produced by diagenetic processes or low-temperature thermogenic reactions at greater depths. Such microbial generation is active even recently [19]. The deep geochemical indicators generally point to relatively short migration pathways of gases between the "generation kitchen" and the traps [19]. According to Hunt [20], only a few percent of hydrocarbons generated in source rocks can be accumulated in traps whereas the rest become dispersed or trapped within the source rocks. Consequently, a significant volume of hydrocarbons generated in the Carpathian Foredeep sediments might have been trapped also in Miocene heterolithic or mudstone-claystone sequences, forming the "hybrid" deposits [21]. This opinion is confirmed by numerous hydrocarbon shows observed in wells completed in the study area. Hence, we suggest that the surface geochemical anomalies may reflect the microseepage of gaseous hydrocarbons not only from conventional accumulations but also from the zones of intensive hydrocarbon generation within the mudstoneclaystone formations. In the Carpathian Foredeep, such formations host hydrocarbon source rocks, but when thin sandstone/mudstone intercalations and/or alternations appear within the formations, they may accumulate the gas, as well.

The research seeks to explain the reasons of observed regularities in the distribution of surface geochemical anomalies in a selected contact zone of the Carpathian orogen and the Carpathian Foredeep. Analysis of the surface geochemical pattern integrated with both the seismic and drilling data enabled us to distinguish the zones of increased hydrocarbon potential.

\section{Geological Setting and Petroleum Occurrences of the Study Area}

2.1. Tectonics, Stratigraphy, and Lithology. The study area is located at the contact of two regional tectonic units: the
Carpathian Foredeep and the Outer Carpathians (see Figure 1(a)). The Carpathian Foredeep is an asymmetric peripheral foreland basin filled mostly with Miocene clastic sediments (molasses), up to $3 \mathrm{~km}$ thick, underlain by platform successions. The northern margin of the foredeep is erosional whereas the southern one is determined by the front of the Outer (Flysch) Carpathians thrusted at a low angle over the Miocene formations filling the foredeep [22-25]. The front of the Flysch Carpathians is marked by a narrow zone of folded Miocene strata [26]. North of the folded Miocene zone, the autochthonous Miocene sequences occupy the outer part of the Carpathian Foredeep $[23,26,27]$. The basement of the central portion of the foredeep is built of Mesozoic sediments whereas its top surface is shaped by the morphology of Badenian evaporites and shows characteristic, significant topographic prominences interpreted as a system of paleovalleys, which merge near Brzesko town into a single valley and then plunge beneath the Carpathian Overthrust [28].

The oldest rocks encountered in the study area are Precambrian sediments [29]. Higher in the sequence, the Lower Carboniferous carbonates appear (see Figure 2) followed by Lower Triassic deposits recognized only in the vicinity of Brzesko town [31]. The overlying Jurassic strata include terrigenous sediments (Dogger) and carbonates (Malm). The strongly dissected post-Jurassic erosional surface is covered by an Upper Cretaceous succession.

The Miocene succession of the Carpathian Foredeep includes a number of formal and informal stratigraphic units [28]. In the Brzesko-Wojnicz area, the Miocene sediments are traditionally classified into the Badenian and the Sarmatian (see Figure 2). In the early Badenian, the so-called "outer basin" of the Carpathian Foredeep was formed [26]. In its southern part, the clayey-sandy sediments of the Skawina Formation, up to $1000 \mathrm{~m}$ thick, were deposited [30, 32, 33] whereas in the northeastern part, the stratigraphic equivalent of the Skawina beds are clayey-sandy deposits of the Baranów beds $[26,34]$. Up the sequence, evaporites appear, which provide the main correlation horizon of the foredeep [35]. These are followed by the Chodenice beds developed as claystones with minor sandy and marly interbeds and by the clayeysandy Grabowiec beds with the Bogucice sands at the bottom [36] (see Figure 2).

The folded Miocene succession includes two units: Stebnik and Zgłobice. The Stebnik Units comprise Lower and Middle Miocene strata encountered only at the front and beneath the flysch Skole Unit [35]. In the central part of the Carpathian Foredeep, the deformed Miocene strata are named the Zgłobice Unit (see Figure 2). Usually, it forms a narrow (some hundreds of meters) zone of Badenian-Sarmatian sediments organized into three slices: southernmost tectonically highest Dębno slice, central Wojnicz slice (see Figure 1(b)), and northernmost tectonically lowest Biadoliny slice [31]. Under the Zgłobice Unit, there is a prominent morphological depression, which is a direct extension of an erosional valley system known from the Carpathian foreland [28].

2.2. Petroleum System. The oil and gas deposits of the Carpathian Foredeep are reservoired in two main structural 

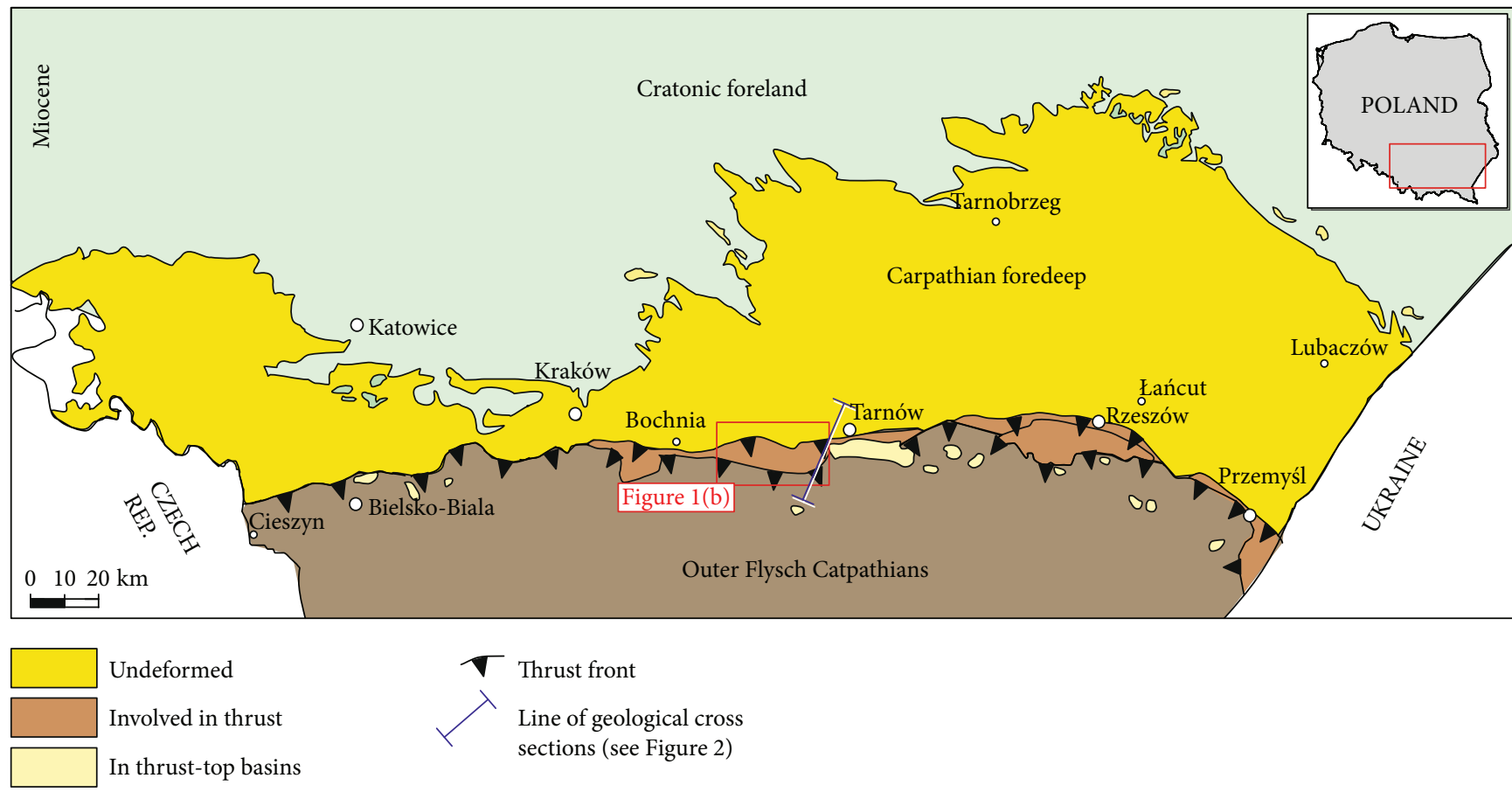

(a)

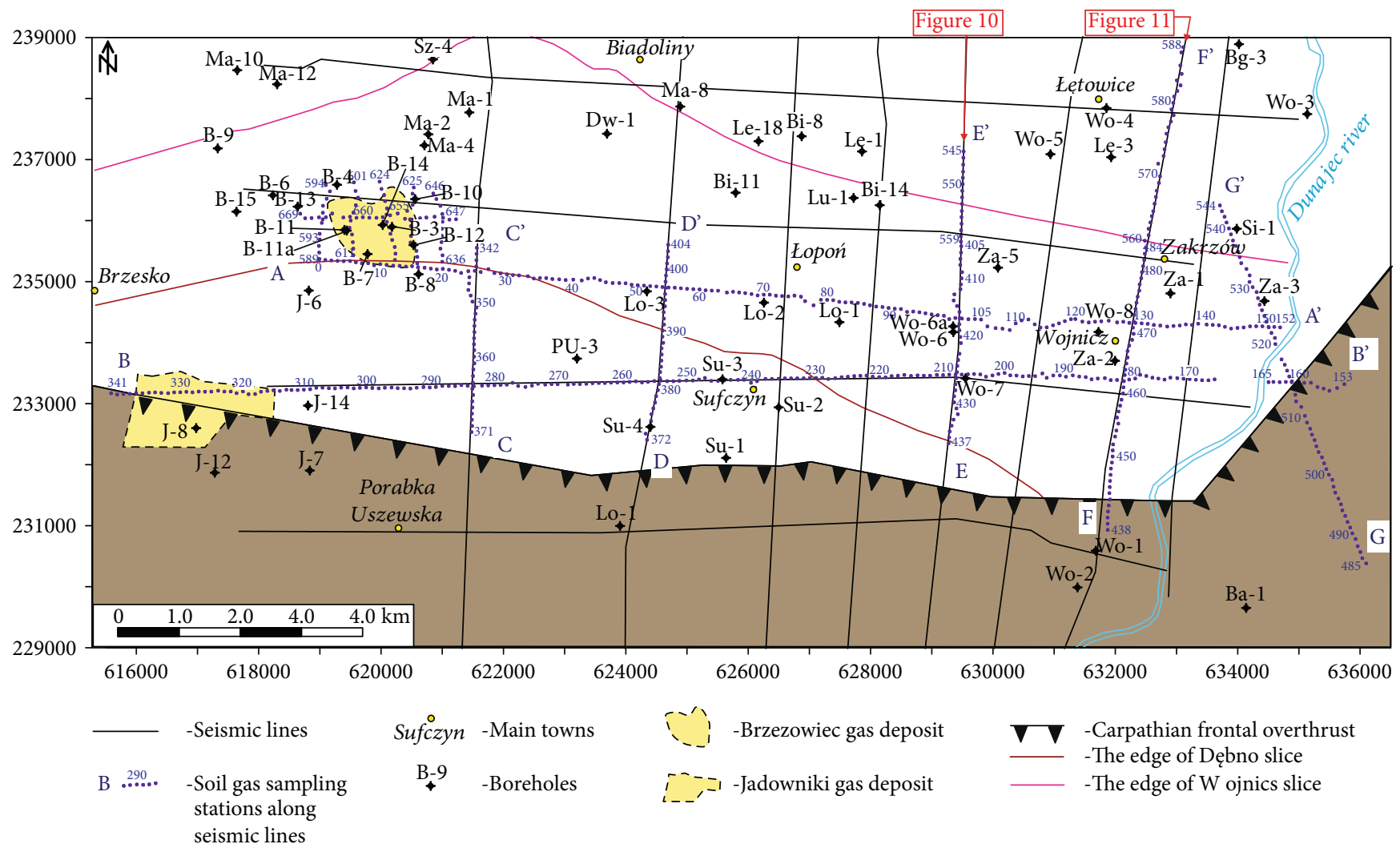

(b)

Figure 1: Location of the study area (rectangle) at the background of (a) a simplified geological map of the Outer Carpathians and their foreland (after [13], modified) and (b) the detailed location of soil gas sampling stations and boreholes as well as the main tectonic units.

units: the Mesozoic-Paleozoic basement (both the oil and the gas deposits) and the Miocene cover (only the highmethane gas deposits) [37]. In the basement, the commercial hydrocarbon accumulations were discovered in several stratigraphic units: in the Cenomanian sandstones, in the Malm limestones, and in the Lower Carboniferous/Upper 


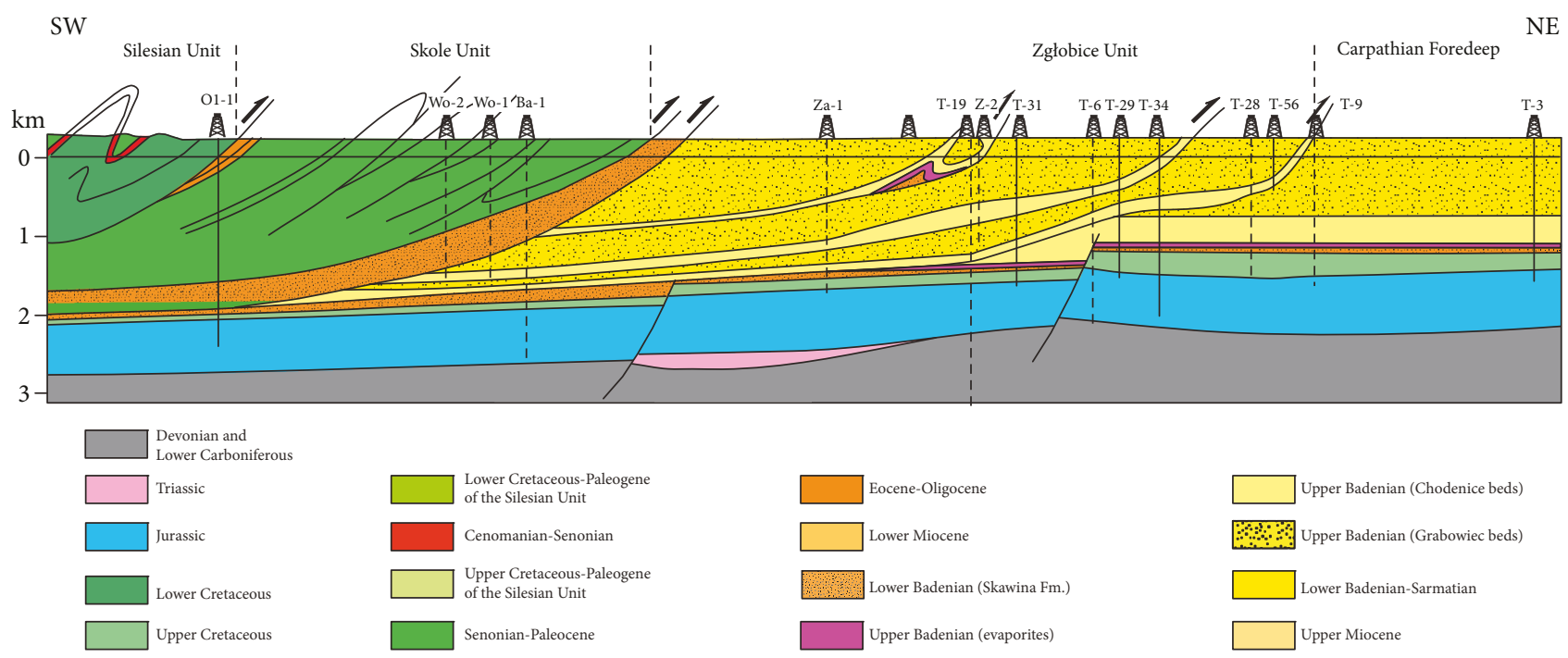

Figure 2: Geological cross section through the marginal part of the Polish Carpathians west of Tarnów (after [30], modified).

TABle 1: Molecular composition and hydrocarbon ratios of natural gases from autochthonous Miocene strata and Mesozoic basement.

\begin{tabular}{|c|c|c|c|c|c|c|c|c|c|c|c|}
\hline \multirow{2}{*}{ Well } & \multirow{2}{*}{ Depth (m) } & \multirow{2}{*}{ Age of reservoir } & \multicolumn{7}{|c|}{ Molecular composition (vol.\%) } & \multicolumn{2}{|c|}{ Hydrocarbon ratios } \\
\hline & & & $\mathrm{CH}_{4}$ & $\mathrm{C}_{2} \mathrm{H}_{6}$ & $\mathrm{C}_{3} \mathrm{H}_{8}$ & $\mathrm{C}_{4} \mathrm{H}_{10}+$ & $\mathrm{N}_{2}$ & $\mathrm{CO}_{2}$ & $\mathrm{He}$ & $\mathrm{C}_{1} / \Sigma\left(\mathrm{C}_{2}-\mathrm{C}_{5}\right)$ & $\mathrm{C}_{2} / \mathrm{C}_{3}$ \\
\hline Le- $11^{1}$ & $575-594$ & Miocene & 98.6 & 0.60 & 0.09 & 0.069 & 0.48 & 0.14 & 0.007 & 129.9 & 6.7 \\
\hline Sz- $18^{1}$ & $815-841$ & Miocene & 98.2 & 0.66 & 0.11 & 0.099 & 0.86 & 0.08 & 0.010 & 113.0 & 6.0 \\
\hline $\mathrm{Bc}-11^{1}$ & $839-900$ & Miocene & 99.5 & 0.12 & 0.03 & 0.043 & 0.10 & 0.04 & 0.21 & 515.5 & 4.0 \\
\hline $\mathrm{Ta}-45^{1}$ & $2243-2257$ & Miocene & 77.0 & 1.34 & 0.47 & 0.580 & 20.2 & 0.47 & 0.049 & 32.2 & 2.9 \\
\hline $\mathrm{Bc}-3^{2}$ & $1346-1352$ & Cenomanian & 98.6 & 0.32 & 0.06 & 0.110 & 0.89 & 0.04 & 0.01 & 201.2 & 5.3 \\
\hline $\mathrm{Wi}-5^{2}$ & $1450-1486$ & Upper Jurassic & 63.6 & 1.88 & 0.60 & 0.500 & 28.6 & 4.95 & 0.06 & 21.3 & 3.1 \\
\hline
\end{tabular}

${ }^{12}$ After [18]; after [38].

Devonian limestones and dolomites. The direct seals are provided by Miocene strata, Cretaceous marls, and the Carpathian flysch units. In the remaining Mesozoic and Paleozoic stratigraphic units, only traces of gaseous and liquid hydrocarbons have been encountered to date [38, 39]. The Miocene successions host multihorizontal deposits of high-methane gas (see Table 1) accumulated within the structural and stratigraphic traps $[2,3,16]$. Diversified geological settings of particular oil and gas deposits point out to different ages of traps formed in the Early Cretaceous or in the Miocene, as well as to younger ages of hydrocarbon generation, migration, and accumulation [18, 38].

In the study area, two hydrocarbon deposits were discovered. The first one is the Brzezowiec gas deposit (see Figure 1(b)) reservoired in both the Miocene and the Cenomanian strata. These are two independent accumulations of different geological settings but of almost the same molecular (see Table 1) and isotopic compositions [18, 38]. In both the traps, bacterial Miocene-sourced gas has accumulated [38], dominated by methane with minor amounts of higher alkanes and nitrogen. However, the shallower Miocene gas horizon shows higher helium content than the deeper Cenomanian horizon (see Table 1). The Brzezowiec gas deposit is currently exploited. The Jadowniki gas deposit is located southwest of the Brzezowiec deposit (see Figure 1(b)). The gas is accumulated in Lower Badenian sediments, at a depth interval of 1100-1220m [37]. The trap occurs under the overthrust of the Carpathian marginal flysch units and the Dębno slice built of folded Miocene sediments of the Zgłobice Unit (see Figure 1(b)). The Jadowniki deposit is currently in an initial stage of assessment [1].

2.3. Hydrocarbon Shows during Drillings and the Results of Well Testing. In the study area, some tens of wells had been completed in the years 1960-2005 (see Figure 1(b)). In many of them, hydrocarbon shows were observed during the drilling through the Miocene strata, from small gas traces in the drilling mud through high mud saturation up to gas explosions (see Table 2). It must be emphasized that common, strong hydrocarbon shows were observed at depths from several hundreds of meters down to almost $2000 \mathrm{~m}$. This fact suggests gas saturation of not only the sandstone horizons but also the Miocene mudstones. Also, the results of tests of completed wells were diversified. In some wells, only the inflows of reservoir waters were noticed whereas in the others, gas-saturated waters appeared and in 9 wells, 
TABLE 2: Hydrocarbon shows during the drillings and the results of well tests (after unpublished data of the POGC).

\begin{tabular}{|c|c|c|c|c|}
\hline Well (year of drilling) & Depth (m) & Hydrocarbon shows during drilling & Results of well testing & $\begin{array}{c}\text { Gas flow rate after } \\
\text { well testing }\end{array}$ \\
\hline Ba-1 (1986) & 3003 & - & Traces of natural gas & - \\
\hline Bi-8 (1964) & 1378 & Smell of oil in cores & Formation water & - \\
\hline Bi-11 (1965) & 2446 & $\begin{array}{l}\text { Traces of oil and gas in drilling } \\
\text { mud, blowout of drilling mud }\end{array}$ & Formation water & - \\
\hline Bi-14 (1969) & 1015 & - & - & - \\
\hline Le-1 (1979) & 1668 & - & $\begin{array}{l}\text { Formation water with traces } \\
\text { of natural gas }\end{array}$ & - \\
\hline Le-3 (1978) & 1751 & - & $\begin{array}{c}\text { Saltwater, saltwater with traces } \\
\text { of natural gas }\end{array}$ & - \\
\hline Le-18 (1993) & 1615 & - & Formation water, formation fluid & - \\
\hline Lp-1 (1968) & 1003 & - & Natural gas, natural gas + formation water & $13 \mathrm{~m}^{3} / \mathrm{min}$ \\
\hline Lp-2 (1969) & 1006 & - & Saltwater with traces of gas & - \\
\hline Lp-3 (1981) & 1600 & - & $\begin{array}{l}\text { Natural gas }+ \text { formation water, low } \\
\text { flow of natural gas }\end{array}$ & $7.1 \mathrm{~m}^{3} / \mathrm{min}$ \\
\hline Lu-1 (2005) & 1830 & Drilling mud saturated by gas & $\begin{array}{c}\text { Formation water, low flow } \\
\text { of natural gas }\end{array}$ & - \\
\hline PU-3 (1969) & 2332 & - & Formation water + natural gas & - \\
\hline Si-1 (1963) & 2048 & Traces of gas in drilling mud & - & - \\
\hline Su-1 (1971) & 2362 & Drilling mud saturated by gas & $\begin{array}{c}\text { Formation water saturated by gas, } \\
\text { traces of gas, natural gas }\end{array}$ & $12.5 \mathrm{~m}^{3} / \mathrm{min}$ \\
\hline Su-2 (1972) & 1215 & - & $\begin{array}{l}\text { Formation water, formation } \\
\text { water + natural gas }\end{array}$ & - \\
\hline Su-3 (1972) & 1314 & - & $\begin{array}{c}\text { Saltwater with traces of gas, low flow } \\
\text { of natural gas }\end{array}$ & $11 \mathrm{~m}^{3} / \mathrm{min}$ \\
\hline Su-4 (1972) & 1405 & - & Natural gas & $\sim 4.0 \mathrm{~m}^{3} / \mathrm{min}$ \\
\hline Wo-1 (no data) & 2205 & - & - & - \\
\hline Wo-2 (1978) & 2715 & - & $\begin{array}{l}\text { Formation water, low flow } \\
\text { of gas + formation water }\end{array}$ & - \\
\hline Wo-3 (1968) & 1007 & - & Saltwater & - \\
\hline Wo-4 (1968) & 1001 & Blowout of drilling mud & Saltwater + traces of gas & - \\
\hline Wo-5 (1968) & 1006 & - & - & - \\
\hline Wo-6 (1968) & 578 & Gas explosion & Natural gas & $68 \mathrm{~m}^{3} / \mathrm{min}$ \\
\hline Wo-6A (1968) & 1198 & $\begin{array}{l}\text { Drilling mud saturated by gas, } \\
\text { blowout of drilling mud }\end{array}$ & Saltwater, traces of gas & - \\
\hline Wo-7 (1969) & 985 & - & $\begin{array}{c}\text { Traces of gas }+ \text { formation water, } \\
\text { traces of gas }\end{array}$ & - \\
\hline Wo-8 (1969) & 1006 & - & Natural gas & $63 \mathrm{~m}^{3} / \mathrm{min}$ \\
\hline Za-1 (1964) & 2631 & $\begin{array}{l}\text { Traces of gas in drilling mud, } \\
\text { hydrocarbons in cores, smell of } \mathrm{H}_{2} \mathrm{~S}\end{array}$ & $\begin{array}{c}\text { Natural gas }+ \text { formation water, } \\
\text { natural gas }\end{array}$ & $22.7 \mathrm{~m}^{3} / \mathrm{min}$ \\
\hline Za-2 (1966) & 1257 & Gas explosion & Formation water & - \\
\hline Za-3 (1965) & 1250 & Flow of gas with saltwater & Natural gas & $14.8 \mathrm{~m}^{3} / \mathrm{min}$ \\
\hline Za-5 (1969) & 1016 & - & - & - \\
\hline
\end{tabular}

The list does not include data from wells located within the Brzezowiec and Jadowniki fields.

significant gas inflows occurred, from about 4 to even $68 \mathrm{~m}^{3} / \mathrm{min}$ (see Table 2). Unfortunately, most of these wells have been abandoned due to low gas inflows. However, most of these wells have been completed many decades ago when modern secondary treatment methods, now routinely applied to claystone-mudstone and shale formations, had not been invented.

\section{Methodology}

3.1. Field Sampling of Soil Gases and Analytical Procedure. The field component of the research included geochemical sampling at 670 stations spaced 100 meters along 7 seismic profiles and along 6 short lines positioned over the Brzezowiec gas deposit (see Figure 1(b)). The soil gas samples were 
collected during the 3 sampling sessions: 31.10.201730.11.2015, 15-17.04.2016, and 18-19.04.2017, when 405, 140 , and 125 samples were taken, respectively. Soil gas samples were collected with a special geochemical probe, gastight syringe, and vessel. The probe was hammered down to 1.2-meter depth, and gas was drawn with a gas-tight syringe and injected into an evacuated vessel. Details of the sampling procedure were presented in previous publications [40-42].

The molecular composition of soil gases was determined at the Laboratory of Gas Chromatography of the Department of Fossil Fuels. We used Fisons Instruments GC 8160 and Carlo Erba Instruments GC 6300 gas chromatographs equipped with FID and TCD. In each sample, methane, ethane, propane, i-butane, n-butane, neo-pentane, i-pentane, n-pentane, ethylene, propylene, 1-butene, hydrogen, nitrogen, oxygen, and carbon dioxide were determined. The detection limit for FID is 0.01 ppm for hydrocarbons. Analytical precision is $2 \%$ of the measured value and $10 \%$ at the detection limit. The Fisons Instruments gas chromatograph with an FID uses a metal column filled with activated alumina (mesh 100/120). The carrier gas (helium) flow rate was $60 \mathrm{ml} / \mathrm{min}$. The programmed column temperatures were $90^{\circ} \mathrm{C}$ for $3 \mathrm{~min}, 90-200^{\circ} \mathrm{C}$ increment at a $30^{\circ} \mathrm{C} / \mathrm{min}$ rate, and $200^{\circ} \mathrm{C}$ for $3 \mathrm{~min}$. The FID working temperature was $270^{\circ} \mathrm{C}$, the injection chamber temperature was $120^{\circ} \mathrm{C}$, and the volume of each injected sample was $2 \mathrm{ml}$.

TCD detection limits for oxygen and nitrogen are $0.1 \mathrm{vol} \%$, and for carbon dioxide and hydrogen, the detection limits are $100 \mathrm{ppm}$ and $10 \mathrm{ppm}$, respectively, at an estimated precision of $2 \%$ of the measured value and $10 \%$ at the detection limit. The Carlo Erba Instruments GC 6300 gas chromatograph was equipped with a thermal conductivity detector (TCD) and dual-column system. The following analytical conditions were applied: metal columns filled with the Molecular Sieve 5A (for analysis of hydrogen) and HaySep (for analysis of carbon dioxide), carrier gas (argon) flow rate of $30 \mathrm{ml} / \mathrm{min}$, constant column temperature of $65^{\circ} \mathrm{C}$, and sample volume of $2 \mathrm{ml}$ injected with an automatic valve. More details of the methodology of chromatographic analyses were presented in several earlier publications [40-43].

3.2. Statistical Procedure. The basic statistical parameters were calculated separately for measured concentrations of each gaseous component (methane, ethane, propane, ibutane, n-butane, neo-pentane, i-pentane, n-pentane, ethylene, propylene, 1-butene, hydrogen, oxygen, nitrogen, and carbon dioxide). Statistical parameters were also calculated for total alkanes $\mathrm{C}_{2}-\mathrm{C}_{5}$ and total alkenes $\mathrm{C}_{2}-\mathrm{C}_{4}$ as well as for geochemical ratios $\mathrm{C}_{1} / \Sigma\left(\mathrm{C}_{2}-\mathrm{C}_{5}\right), \mathrm{C}_{2} \mathrm{H}_{6} / \mathrm{C}_{3} \mathrm{H}_{8}\left(\mathrm{C}_{2} / \mathrm{C}_{3}\right)$, and $\mathrm{C}_{2} \mathrm{H}_{6} / \mathrm{C}_{2} \mathrm{H}_{4}\left(\mathrm{C}_{2} / \mathrm{C}_{2=}\right)$. These ratios (tabulated in Table 3 ) enabled the preliminary genetic evaluation of gas sources, their character, and the intensity of microbial processes operating in the near-surface zone, which may be controlled by the relative intensity of hydrocarbon microseepage from deep accumulations to the surface.

In order to evaluate relationships between the analyzed components, the Pearson correlation coefficients (PCC) were calculated. Due to the log-normal distribution of hydrocarbon concentrations, the correlations were calculated using
TABle 3: Principal statistical parameters of hydrocarbon ratios calculated for analyzed soil gas components.

\begin{tabular}{lccc}
\hline \multirow{2}{*}{ Statistical parameters } & \multicolumn{3}{c}{ Hydrocarbon ratios } \\
& $\mathrm{C}_{1} / \Sigma\left(\mathrm{C}_{2}-\mathrm{C}_{5}\right)$ & $\mathrm{C}_{2} / \mathrm{C}_{3}$ & $\mathrm{C}_{2} / \mathrm{C}_{2=}$ \\
\hline Minimum & 0.22 & 0.01 & 0.30 \\
Maximum & 145898.0 & 16.71 & 16.5 \\
Median & 63.7 & 3.20 & 1.85 \\
Mean & 448.6 & 3.87 & 2.49 \\
Standard deviation & 6628.0 & 2.60 & 2.40 \\
Skewness & 21.7 & 2.05 & 2.25 \\
\hline
\end{tabular}

the logarithm of measured values. Hence, the "zero" concentrations (i.e., values below the detection limits of FID and/or TCD) were omitted. The correlations were determined qualitatively by comparison of the concentration diagrams of various components and calculation of percentages of fitting plots.

Two plots were constructed for the relationship between ethane and propane. The first plot represents the whole data set; the second depicts ranges of values distinguished on the basis of a cumulative frequency diagram of the $C_{2} / C_{3}$ ratio. These ranges represent the type of subsurface hydrocarbon accumulations (e.g., oil, condensate gas, and dry gas) and were shown on cross sections as circles of different colours.

Based on the measured hydrocarbon concentrations in soil gas samples, a cross-plot of the relationship between values of $\log \left(\mathrm{C}_{2} / \mathrm{C}_{3}+\mathrm{C}_{4}\right)$ and $\log \left(\mathrm{C}_{1} / \mathrm{C}_{2}+\mathrm{C}_{3}\right)$ ratios was produced [44].

In order to objectively determine the anomalies, the iteration method was applied for the determination of background values [44]; then, the threshold values were calculated and the geochemical anomalies were identified. Background values were determined for the sets of concentrations of methane, total alkanes $\mathrm{C}_{2}-\mathrm{C}_{5}$, and total alkenes $\mathrm{C}_{2}-\mathrm{C}_{4}$. As the samples were collected during the 3 field sessions, the background values of each component were determined separately for each sampling session. Then, such calculated background values were applied for the normalization of concentrations within the sets. Hence, the influence of climatic conditions during the sampling sessions was eliminated.

In order to reduce measured values to their natural distributions, the normalized values of analyzed geochemical indices were filtered. Although this procedure partly distorts the patterns obtained, it facilitates their interpretation. The values of analyzed geochemical indices were filtered with a three-point filter [44-46].

The distributions of normalized and filtered concentrations of total alkanes $\mathrm{C}_{2}-\mathrm{C}_{5}$ were drawn against the structural map of the bottom surface of Miocene succession together with the localization of hydrocarbon deposits and the position of the Carpathian Overthrust front, the contour of the Dębno slice northern margin and the margin of the Wojnicz slice, the latter being the backward thrust of the Chodenice and the Grabowiec beds [28]. Additionally, the contours of hydrocarbon anomalies and the relative intensities of hydrocarbon shows in the wells (represented by circles of various 
TABLE 4: Principal statistical parameters of alkane concentrations in analyzed soil gas samples.

\begin{tabular}{|c|c|c|c|c|c|c|c|c|c|}
\hline \multirow{2}{*}{ Statistical parameters } & \multicolumn{8}{|c|}{ Alkanes $(\mathrm{ppm})$} & \multirow{2}{*}{ Total alkanes $\mathrm{C}_{2}-\mathrm{C}_{5}$} \\
\hline & $\mathrm{CH}_{4}$ & $\mathrm{C}_{2} \mathrm{H}_{6}$ & $\mathrm{C}_{3} \mathrm{H}_{8}$ & $\mathrm{i}-\mathrm{C}_{4} \mathrm{H}_{10}$ & $\mathrm{n}-\mathrm{C}_{4} \mathrm{H}_{10}$ & neo- $\mathrm{C}_{5} \mathrm{H}_{12}$ & i- $\mathrm{C}_{5} \mathrm{H}_{12}$ & $\mathrm{n}-\mathrm{C}_{5} \mathrm{H}_{12}$ & \\
\hline Minimum (ppm) & 0.7 & b.d.l. & b.d.l. & b.d.l. & b.d.l. & b.d.l. & b.d.l. & b.d.l. & b.d.l. \\
\hline Maximum (ppm) & 271000.0 & 45.2 & 3.6 & 0.52 & 5.53 & 0.01 & 0.4 & 0.05 & 45.3 \\
\hline Median (ppm) & 2.0 & 0.02 & b.d.l. & b.d.l. & b.d.l. & b.d.l. & b.d.l. & b.d.l. & 0.02 \\
\hline Mean (ppm) & 576.4 & 0.10 & 0.01 & b.d.l. & 0.01 & b.d.l. & b.d.l. & b.d.l. & 0.13 \\
\hline Standard deviation (ppm) & 11250.3 & 1.75 & 0.14 & 0.02 & 0.22 & b.d.l. & b.d.l. & b.d.l. & 1.79 \\
\hline Skewness (ppm) & 22.1 & 25.8 & 24.6 & 22.3 & 25.4 & 13.4 & 19.0 & 16.3 & 24.3 \\
\hline Percentage of samples* (\%) & 100.0 & 71.8 & 25.8 & 4.6 & 8.4 & 0.6 & 0.45 & 0.7 & 73.3 \\
\hline
\end{tabular}

* Percentage of samples with concentration of a given component over the detection limit; b.d.l.: below detection limit.

diameters) were marked. This display enabled us to compare the positions of geochemical anomalies with the intensities of hydrocarbon shows observed in the wells.

Changes of measured as well as normalized and filtered values of concentrations were presented as plots superimposed onto the seismic cross sections. These plots are also presented for geochemical ratios $\left(\mathrm{C}_{2} / \mathrm{C}_{3}, \mathrm{C}_{2} / \mathrm{C}_{2}\right)$.

3.3. Method of Evaluation of Hydrocarbon Shows during the Drillings and the Results of Well Testing. In order to evaluate the relationships between the distribution of surface geochemical anomalies and the results of well tests, weight values were attributed to hydrocarbon shows appearing in the wells and to the results of soil gas sampling, as listed in Table 2. It was assumed that the most important were the gas inflows together with their yields. The next in sequence were gas inflows with reservoir waters, then gas-bearing reservoir waters, then reservoir waters with gas traces, and so on, to which successively lower weights were attributed. Consequently, the hydrocarbon shows observed during the drilling operations were evaluated: from "gas explosions" and eruptions of drilling mud with gas (highest weight values) to high gas contents in the mud, low gas contents in the mud, traces of gas in the mud, and scant gas in the mud (lowest weights). If various types of gas shows were recorded during particular drillings, their weights were added to give a total. Hence, each well obtained numerical values representing the relative intensity of its gas shows.

It must be emphasized that Table 2 does not contain wells localized within the contours of both the Brzezowiec and the Jadowniki gas deposits. We assumed that gas shows recorded in these wells are less important in relation to the whole deposit as sources of hydrocarbon dispersion; that is, the distribution of surface geochemical anomalies should be referred to the position of the entire area of a particular deposit.

\section{Results and Discussion}

4.1. Statistical Evaluation of Hydrocarbon Concentrations Measured in Soil Gas Samples. Using the statistical parameters listed in Table 4, it is concluded that apart from methane, which was recorded in all analyzed samples, the second main alkane is ethane. The shares of other alkanes (propane, butanes) are very low. The relationships between statistical parameters of $\mathrm{CH}_{4}$ and successive homologues indicate that the occurrence of heavier gaseous alkanes in the nearsurface zone results from microseepage from subsurface accumulations $[4,5,40-42,47-50]$. The dominance of light gaseous alkanes in the near-surface zone may suggest their migration mostly from Miocene strata where methane is the main component (see Table 1).

The maximum methane concentration (over 27 vol.\%) was found in the number 120 sample. However, this methane is presumably of recent origin and was generated in the near-surface zone, as revealed by high values of $\mathrm{C}_{1} / \Sigma\left(\mathrm{C}_{2}-\mathrm{C}_{5}\right)$ coefficient-almost 6000 [4, 41, 51-54]. Calculation of this coefficient for each collected sample enabled us to preliminary evaluate the origin of detected methane, thus eliminating the expensive and laborious stable isotope analyses.

In the case of concentrations of methane and total alkanes $\mathrm{C}_{2}-\mathrm{C}_{5}$, attention must be paid to relatively large differences between mean and median values, which indicate significant numbers of anomalous values in both data populations. It is confirmed by relatively high positive skewness in concentrations of all alkanes.

Among unsaturated hydrocarbons, ethylene was most commonly indicated (see Table 5). Its significant concentrations relative to ethane may suggest diversified microseepage of alkanes towards the surface or the first step in oxidation. Lower skewness values calculated for alkenes in relation to alkanes point out to the lower number of anomalous values of their concentrations.

The presence of light gaseous alkenes in analyzed soil gas samples is still a matter of discussion. Many authors insist that alkenes are generated exclusively in the near-surface zone by biochemical reactions. New results $[54,55]$ revealed that the stepwise oxidation of an alkane by bacterial processes is occurring in the following order: alkane $\rightarrow$ alkene $\rightarrow$ alcohol $\rightarrow$ aldehyde $\rightarrow$ carboxylic acid $\rightarrow$ acetate $\rightarrow$ carbon dioxide. Moreover, Klusman [54, 55] claims that these bacterial processes are occurring in a limited supply of oxygen and depend on seasons, particularly temperature of the soil and humidity [56]. Other authors [12, 51, 57] assume that time is an important parameter which controls the intensity of biochemical reactions. The longer the alkanes remain under the influence of particular stable conditions, the greater their bacterial destruction. Thus, the active (relatively fast) migration of alkane molecules along fractures and faults does not leave sufficient time for their stepwise oxidation even 
TABle 5: Principal statistical parameters of alkene and nonhydrocarbon gas concentrations in analyzed soil gas samples.

\begin{tabular}{lcccccccc}
\hline \multirow{2}{*}{ Statistical parameters } & \multicolumn{3}{c}{ Alkenes (ppm) } & \multirow{2}{*}{ Total alkenes $\mathrm{C}_{2}-\mathrm{C}_{4}$} & \multirow{2}{*}{$\mathrm{H}_{2}{ }^{* *}$} & \multirow{2}{*}{$\mathrm{O}_{2}{ }^{* *}$} & \multirow{2}{*}{$\mathrm{N}_{2}{ }^{* *}$} & $\mathrm{CO}_{2}{ }^{* *}$ \\
\hline Minimum (ppm) & b.d.l. & b.d.l. & b.d.l. & b.d.l. & b.d.l. & 6.2 & 61.0 & 0.01 \\
Maximum (ppm) & 0.37 & 0.11 & 0.09 & 0.49 & 0.232 & 20.7 & 89.3 & 6.29 \\
Median (ppm) & 0.005 & b.d.l. & b.d.l. & 0.01 & b.d.l. & 18.2 & 79.1 & 0.31 \\
Mean (ppm) & 0.01 & 0.001 & 0.002 & 0.02 & 0.009 & 17.9 & 79.3 & 0.47 \\
Standard deviation (ppm) & 0.02 & 0.01 & 0.01 & 0.03 & 0.020 & 1.9 & 1.9 & 0.57 \\
Skewness (ppm) & 7.4 & 12.7 & 5.4 & 8.1 & 4.5 & -2.4 & -0.2 & 5.0 \\
Percentage of samples (\%) & 51.2 & 5.1 & 13.1 & 58.2 & 44.5 & 100 & 100 & 100 \\
\hline
\end{tabular}

${ }^{*}$ Percentage of samples with concentration of a given component over the detection limit; ** minimum, maximum, median, mean, and standard deviation value in vol.\%. b.d.l.: below detection limit.

TABLE 6: Pearson correlation coefficients of principal components analyzed in soil gas samples.

\begin{tabular}{|c|c|c|c|c|c|c|}
\hline Component & Methane & Total $\mathrm{C}_{2}-\mathrm{C}_{5}$ alkanes & Total $\mathrm{C}_{2}-\mathrm{C}_{4}$ alkenes & Carbon dioxide & Hydrogen & Oxygen \\
\hline Methane & 1 & $\begin{array}{c}0.54 \\
(491)\end{array}$ & $\begin{array}{c}0.36 \\
(390)\end{array}$ & $\begin{array}{c}0.02 \\
(670)\end{array}$ & $\begin{array}{l}0.19 \\
(298)\end{array}$ & $\begin{array}{l}-0.24 \\
(670)\end{array}$ \\
\hline Total $\mathrm{C}_{2}-\mathrm{C}_{5}$ alkanes & & 1 & $\begin{array}{c}0.62 \\
(327)\end{array}$ & $\begin{array}{c}0.01 \\
(491)\end{array}$ & $\begin{array}{c}0.55 \\
(275)\end{array}$ & $\begin{array}{c}0.04 \\
(491)\end{array}$ \\
\hline Total $\mathrm{C}_{2}-\mathrm{C}_{4}$ alkenes & & & 1 & $\begin{array}{l}-0.07 \\
(390)\end{array}$ & $\begin{array}{c}0.25 \\
(205)\end{array}$ & $\begin{array}{c}0.05 \\
(390)\end{array}$ \\
\hline Carbon dioxide & & & & 1 & $\begin{array}{c}-0.08 \\
(298)\end{array}$ & $\begin{array}{r}-0.49 \\
(670)\end{array}$ \\
\hline Hydrogen & & & & & 1 & $\begin{array}{l}-0.01 \\
(298)\end{array}$ \\
\hline Oxygen & & & & & & 1 \\
\hline
\end{tabular}

The numbers in brackets indicate the numbers of samples included in the calculation.

to alkenes. Hence, the high ratio of saturated-to-unsaturated hydrocarbons may be evidence for relatively active migration of alkanes from deep accumulations towards the surface $[12,51,57,58]$.

The hydrogen concentrations are relatively low (see Table 5) and were detected with the TCD in almost $45 \%$ of the analyzed samples.

The population of oxygen concentrations shows low variability of both the mean and the median values as well as relatively low skewness, which suggests an insignificant number of anomalous concentrations. Moreover, the negative skew documents the asymmetry of its distribution, where anomalies will be the samples with decreased oxygen concentrations. Similar relationships are revealed by nitrogen concentrations (see Table 5). Both the mean and median values of oxygen and nitrogen concentrations show that their statistical distributions are close to normal, as confirmed by very low values of the skewness coefficient.

The concentrations of carbon dioxide include increased anomalous values, as revealed by the mean higher than the median and the positive skewness (see Table 5).

4.2. Correlations between Analyzed Components of Soil Gas. Among the analyzed components of soil gas, the strongest dependence was found for total alkanes $\mathrm{C}_{2}-\mathrm{C}_{5}$ and total alkenes $\mathrm{C}_{2}-\mathrm{C}_{4}$ (see Table 6) even if the calculated correlation coefficient is not very high. This relationship may result from microbial processes, which leads to oxidation of a part of alkanes to alkenes during the gas flux from deep sources [55]. Another argument for such correlation is a relatively high proportion of consistent trends of concentration changes for both hydrocarbon groups indicating a common source (see Figure 3).

Values of total alkanes $\mathrm{C}_{2}-\mathrm{C}_{5}$, regarded by many authors $[4,5,42,51,57]$ as a principal geochemical indicator, show the highest consistency of concentration trends with hydrogen values (see Figure 3). Hence, hydrogen can be accepted (under specific conditions) as an additional, indirect petroleum exploration indicator. Anomalous hydrogen concentrations may indicate localized zones of dense fractures and/or tectonic discontinuities within the rock formations. However, a relatively low value of PCC between alkanes and hydrogen (Table 6) reveals that migration of alkanes towards the surface proceeds not only along the tectonic dislocations but also by microseepage through the systems of microfractures in the overburden. Furthermore, it must be emphasized that, despite the origin from deep sources, hydrogen may well be the product of biodegradation of hydrocarbons at depths [59-61] and/or radiolysis of water or methane [62]. Finally, an alternative hydrogen source can be the dehydrogenation of alkanes, which produces unsaturated hydrocarbons [12]. 


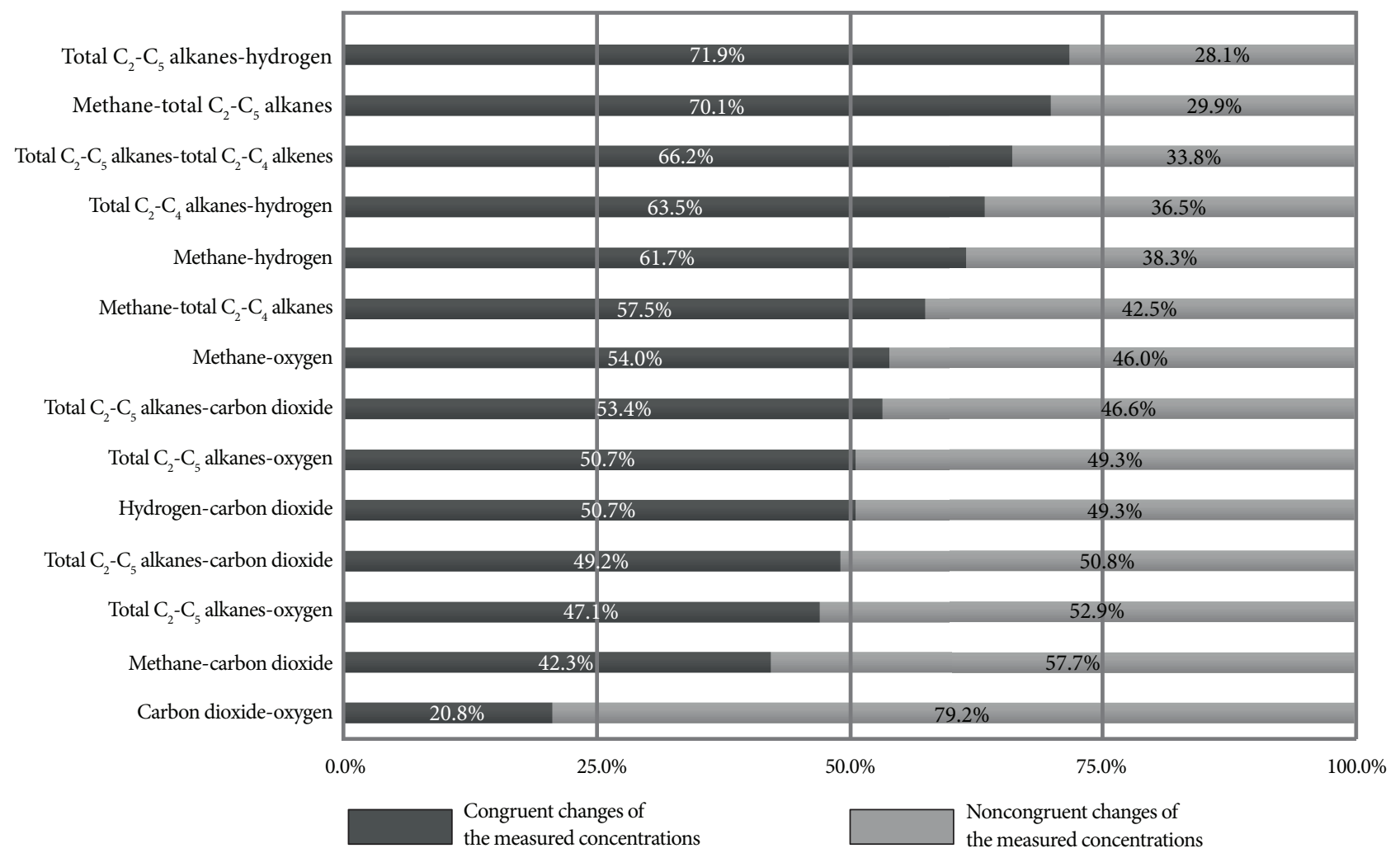

(a)

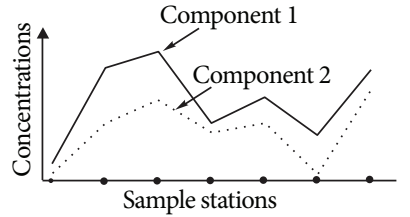

(b)

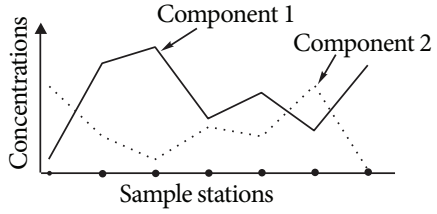

(c)

FIgURE 3: Correlation trends between analyzed components of soil gas (a). Examples of $100 \%$ consistency trends (b) and $100 \%$ inconsistency trends $(c)$ of concentration changes for component pairs between succeeding sampling sites.

Both the methane-carbon dioxide and oxygen-carbon dioxide relationships show clear inconsistency of trends of concentration changes (see Figure 3); that is, increased concentrations of carbon dioxide are accompanied by decreasing values of methane and by a strong drop in oxygen values. Such trends advocate the microbial oxidation of methane in the near-surface zone.

Among hydrocarbons, relatively high correlation coefficients were found among i-butane and n-butane, propane and i-butane, and propane and n-butane, whereas methane showed rather moderate correlation with ethane and no correlation with its higher gaseous homologues. Ethane revealed the strongest correlation with propane and very weak one with butanes (see Table 7). Such relationships indicate that the higher gaseous alkanes do not originate from a single source. Propane, i-butane, and n-butane, which show the strongest mutual correlations, have presumably migrated towards the surface through a system of microfractures from deeper parts of Miocene succession where they were generated by thermogenic processes. On the contrary, methane and ethane were produced mostly by microbial reactions operating within the full thickness of the Miocene suite [18].

Both ethylene and hydrogen show the strongest correlations with ethane (see Table 7), which may suggest their genetic link to microbial processes active within the Miocene formations, similar to methane [18].

\subsection{Statistical Analysis and Evaluation of Hydrocarbon} Ratios. The values of the $\mathrm{C}_{1} / \Sigma\left(\mathrm{C}_{2}-\mathrm{C}_{5}\right)$ ratio vary over 6 orders of magnitude. Their values show a notable difference of median and mean values as well as very high standard deviation (see Table 3). The $\mathrm{C}_{1} / \Sigma\left(\mathrm{C}_{2}-\mathrm{C}_{5}\right)$ exceeded 1000 in six samples, suggesting the presence of recently generated microbial methane. The histogram of $\mathrm{C}_{1} / \Sigma\left(\mathrm{C}_{2}-\mathrm{C}_{5}\right)$ values has an asymmetric pattern and high frequency of the last open interval (see Figure $4(\mathrm{a})$ ). The set of $\mathrm{C}_{1} / \Sigma\left(\mathrm{C}_{2}-\mathrm{C}_{5}\right)$ values contains characteristic subsets: $<40,40-80,80-200$, and $>200$ (see Figure 4(b)). Considering the modal interval, which is 20-40 (see Figure 4(a)), we conclude the dominance of the gas condensate character of deep hydrocarbon dispersion sources [47]. 
TABLe 7: Pearson correlation coefficients of hydrocarbons and hydrogen concentrations in analyzed soil gas samples.

\begin{tabular}{|c|c|c|c|c|c|c|c|}
\hline Component & Methane & Ethane & Propane & i-Butane & n-Butane & Ethylene & Hydrogen \\
\hline Methane & 1 & $\begin{array}{c}0.61 \\
(481)\end{array}$ & $\begin{array}{c}0.36 \\
(173)\end{array}$ & $\begin{array}{l}0.21 \\
(31)\end{array}$ & $\begin{array}{l}0.06 \\
(56)\end{array}$ & $\begin{array}{c}0.46 \\
(343)\end{array}$ & $\begin{array}{c}0.19 \\
(298)\end{array}$ \\
\hline Ethane & & 1 & $\begin{array}{c}0.71 \\
(166)\end{array}$ & $\begin{array}{l}0.31 \\
(30)\end{array}$ & $\begin{array}{l}0.06 \\
(52)\end{array}$ & $\begin{array}{c}0.69 \\
(300)\end{array}$ & $\begin{array}{c}0.55 \\
(273)\end{array}$ \\
\hline Propane & & & 1 & $\begin{array}{l}0.87 \\
(23)\end{array}$ & $\begin{array}{l}0.76 \\
(47)\end{array}$ & $\begin{array}{c}0.65 \\
(126)\end{array}$ & $\begin{array}{c}0.49 \\
(120)\end{array}$ \\
\hline i-Butane & & & & 1 & $\begin{array}{l}0.91 \\
(21)\end{array}$ & $\begin{array}{l}0.58 \\
(21)\end{array}$ & $\begin{array}{l}0.49 \\
(15)\end{array}$ \\
\hline n-Butane & & & & & 1 & $\begin{array}{l}0.46 \\
(40)\end{array}$ & $\begin{array}{l}0.38 \\
(38)\end{array}$ \\
\hline Ethylene & & & & & & 1 & $\begin{array}{c}0.27 \\
(184)\end{array}$ \\
\hline Hydrogen & & & & & & & 1 \\
\hline
\end{tabular}

The numbers in brackets indicate the numbers of samples included in the calculation.

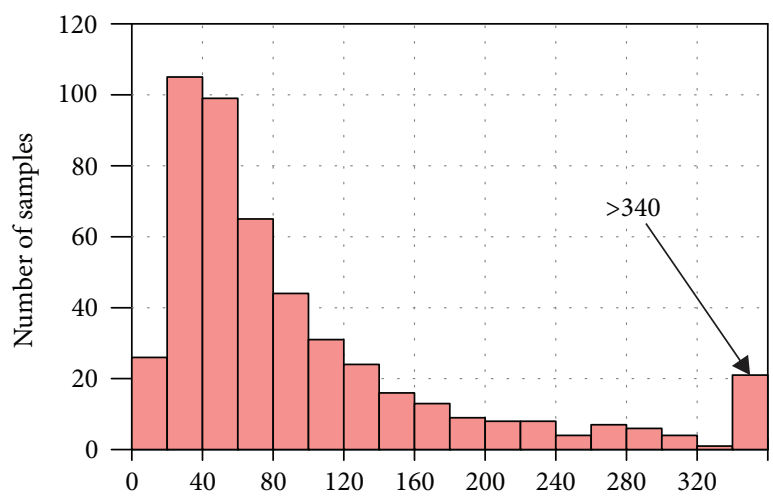

(a)

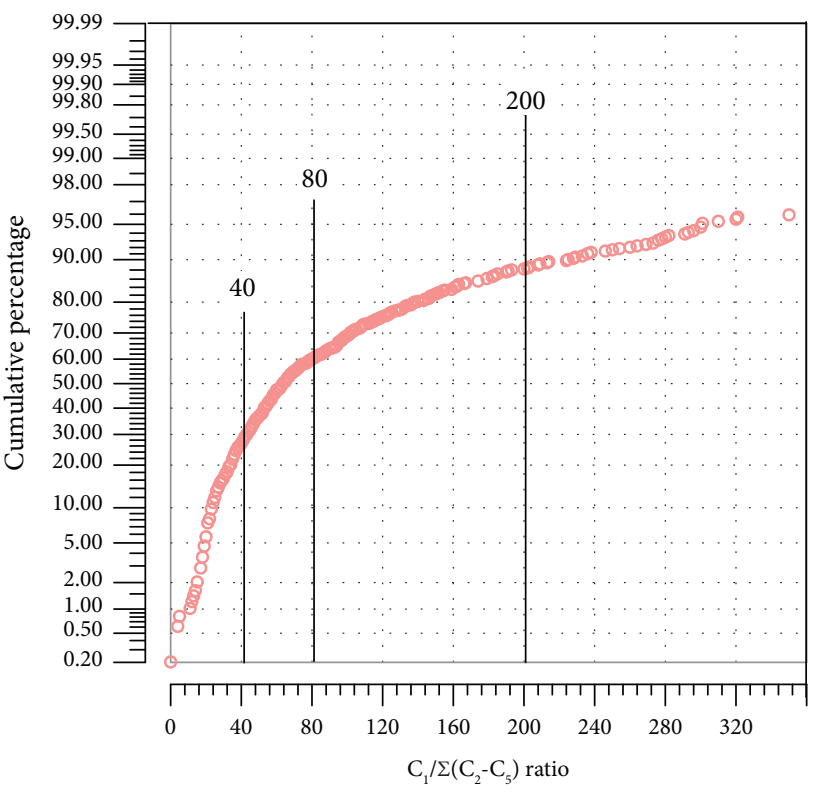

(b)

Figure 4: Histogram (a) and cumulative frequency diagram (b) of $\mathrm{C}_{1} / \Sigma\left(\mathrm{C}_{2}-\mathrm{C}_{5}\right)$ ratios calculated for analyzed soil gas components.

The variability of the $\mathrm{C}_{2} / \mathrm{C}_{3}$ ratio reaches 2 orders of magnitude (see Table 3). The mean value close to the median together with low standard deviation indicates the low number of outliers in this subset. It is confirmed by a unimodal histogram for this ratio (see Figure 5(a)) characterized by positive skewness. The modal class falls into the range from 2 to 3 , which indicates that the strongest surface geochemical signal comes from the accumulations of gas condensate. A comparison of the constructed histogram with the empirical distributions proposed by Nikonov [63] (see Figure 5(c)) reveals also a weak signal, which results from crude oil or nonassociated gas accumulations. In the probability plot of the $\mathrm{C}_{2} / \mathrm{C}_{3}$ ratio, the following subsets were discriminated: $<1.5,1.5-4.0,4.0-7.6$, and $>7.6$ (see Figure $5(\mathrm{~b})$ ). These sequences illustrate the character of deep hydrocarbon accumulations changing from gas condensate to gas with a small yield of oil. The highest frequency of the second subset evident from the probability plot (see Figure 5(b)) proves the dominance of signal characteristic for accumulations of gas condensate.

The correlation between ethane and propane concentrations was presented in the form of the Cartesian coordinate system (see Figure 6(a)). It is characterized by the coefficient of determination $R^{2}=0.76$, which indicates moderate correlation between these two components. This supports our earlier opinion that alkanes detected in the near-surface zone are the result of microseepage from few accumulations of various compositions. However, values of the coefficient of determination for subsets of the $\mathrm{C}_{2} / \mathrm{C}_{3}$ ratio, which determine the correlation between $\mathrm{C}_{2} \mathrm{H}_{6}$ and $\mathrm{C}_{3} \mathrm{H}_{8}$, are much higher (see 


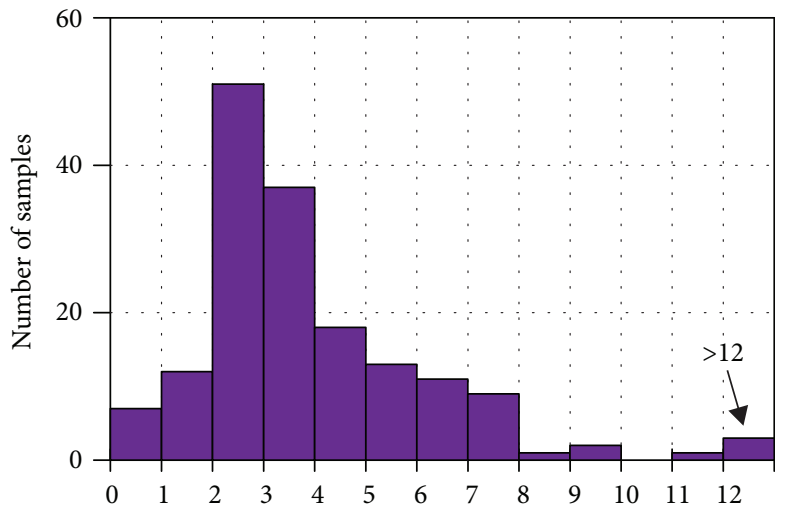

(a)

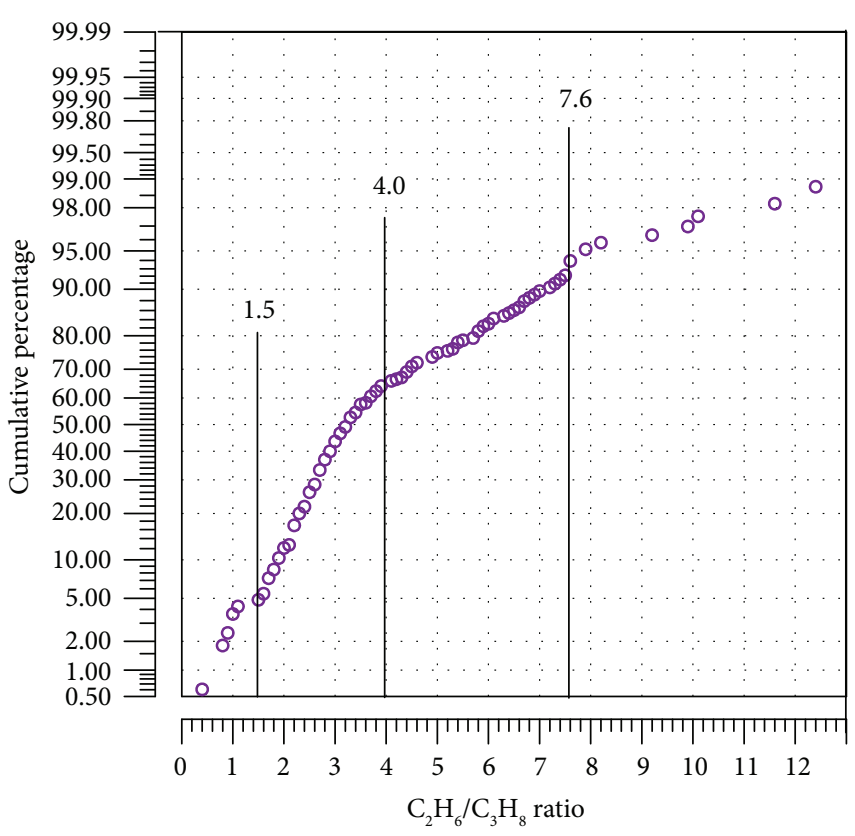

(b)

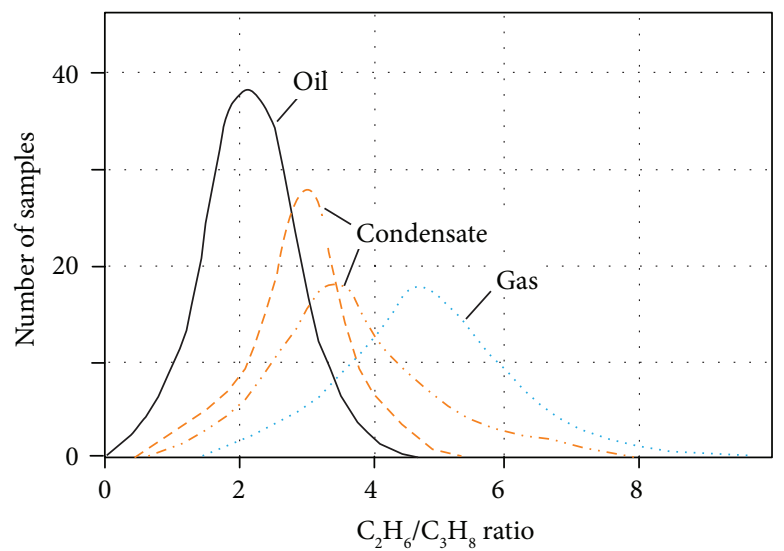

(c)

Figure 5: Histogram (a) and cumulative frequency diagram (b) of the $\mathrm{C}_{2} / \mathrm{C}_{3}$ ratio calculated for soil gas components; distribution of $\mathrm{C}_{2} / \mathrm{C}_{3}$ ratios in world hydrocarbon reservoirs (c) (after [63]).

Figure 6(b)) - for the largest subset (1.5 to 4.0), the coefficient of determination is 0.93 . Once again, it proves the dominance of accumulations containing gas condensate [41, 47].

Similar conclusions can be drawn from analyzing the $\log \left(\mathrm{C}_{2} / \mathrm{C}_{3}+\mathrm{C}_{4}\right)$ versus $\log \left(\mathrm{C}_{1} / \mathrm{C}_{2}+\mathrm{C}_{3}\right)$ plot (see Figure 7 ). This plot contains the points representing the soil gas samples having the anomalous values of total alkanes $\mathrm{C}_{2}-\mathrm{C}_{5}$ (i.e., above the background value). Points representing the soil gases are grouped inside of the areas representing condensate and/or gas accumulation. Additionally, there are also points illustrating the hydrocarbon compositions of gases from wells (Bc-3, Bc-11, Le-11, Sz-18, Ta-45, and Wi-5). Molecular composition as well as values of hydrocarbon ratios of these gases is shown in Table 1. Migration of light hydrocarbons from the deep subsurface to the near-surface zone is very complicated $[6,64]$. All the possible modes of microseepage may occur simultaneously, in proportions and intensities controlled by geological conditions $[65,66]$. The amounts of migrating gases almost always decrease in the following order: methane $>$ ethane $>$ propane $>$ butane. As a result, the flux of hydrocarbons reaching the near-surface zone becomes depleted in larger (heavier) molecules. Taking into account these processes, it is assumed that most components of the analyzed soil gas samples (see Figure 7) represent gases derived from deep sources and show molecular compositions similar to those obtained for gas samples from Wi-5 and Ta-45 wells. Both the wells penetrated gas accumulations in deeper parts of the Miocene suite and basement (see Table 1).

The histogram of $\mathrm{C}_{2} / \mathrm{C}_{2}$ = values is close to be logarithmic and right-skewed (see Figure 8(a)). The following subsets were distinguished: $<1.8,1.8-3.2,3.2-6.0$, and $>6.0$ (see Figure $8(\mathrm{~b})$ ). The statistical distributions attest to the 


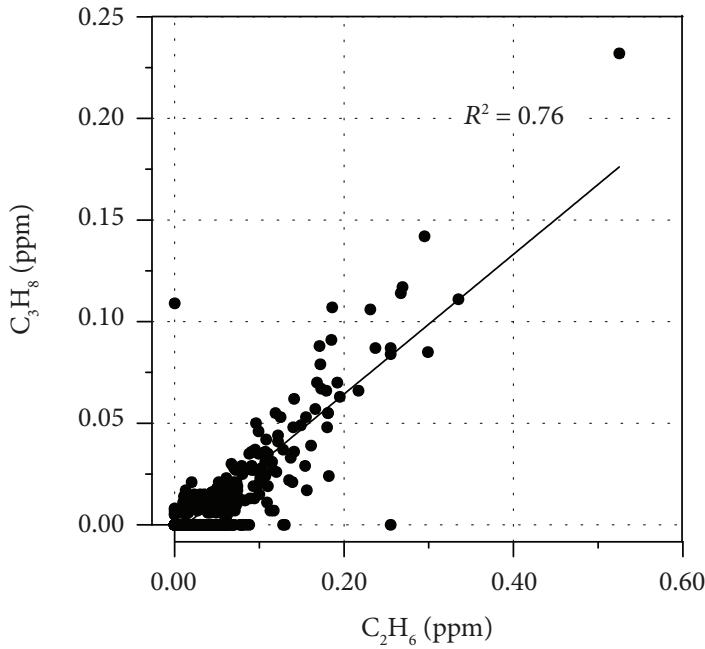

(a)
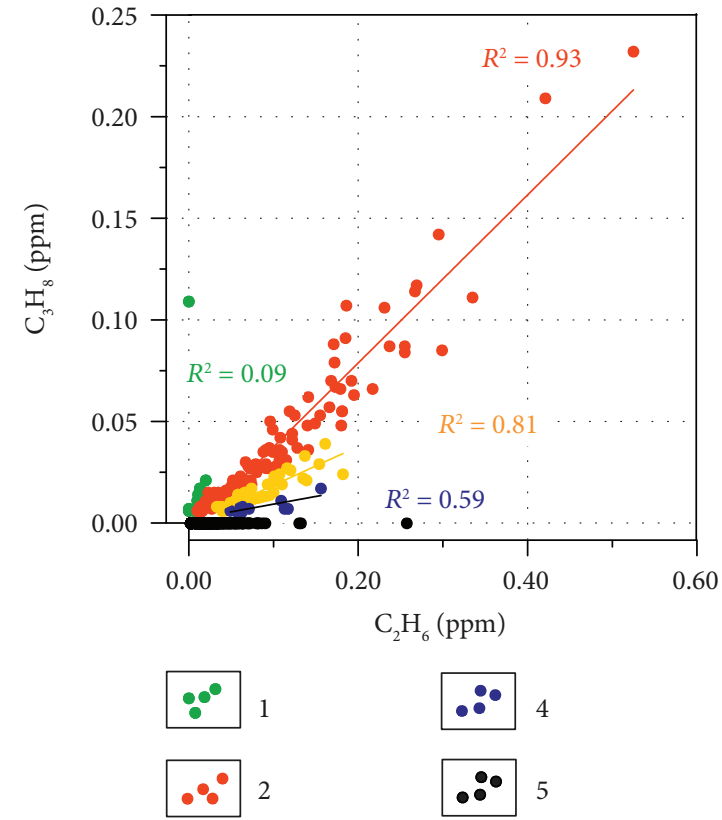

(b)

Figure 6: Scatter plots of ethane versus propane concentrations for the whole dataset (a) and for the following subsets $(b): 1-C_{2} / C_{3},<1.5$; $2-\mathrm{C}_{2} / \mathrm{C}_{3}$, from 1.5 to $4.0 ; 3-\mathrm{C}_{2} / \mathrm{C}_{3}$, from 4.0 to $7.6 ; 4-\mathrm{C}_{2} / \mathrm{C}_{3}$, over 7.6 ; and 5 -propane concentrations below detection limit.

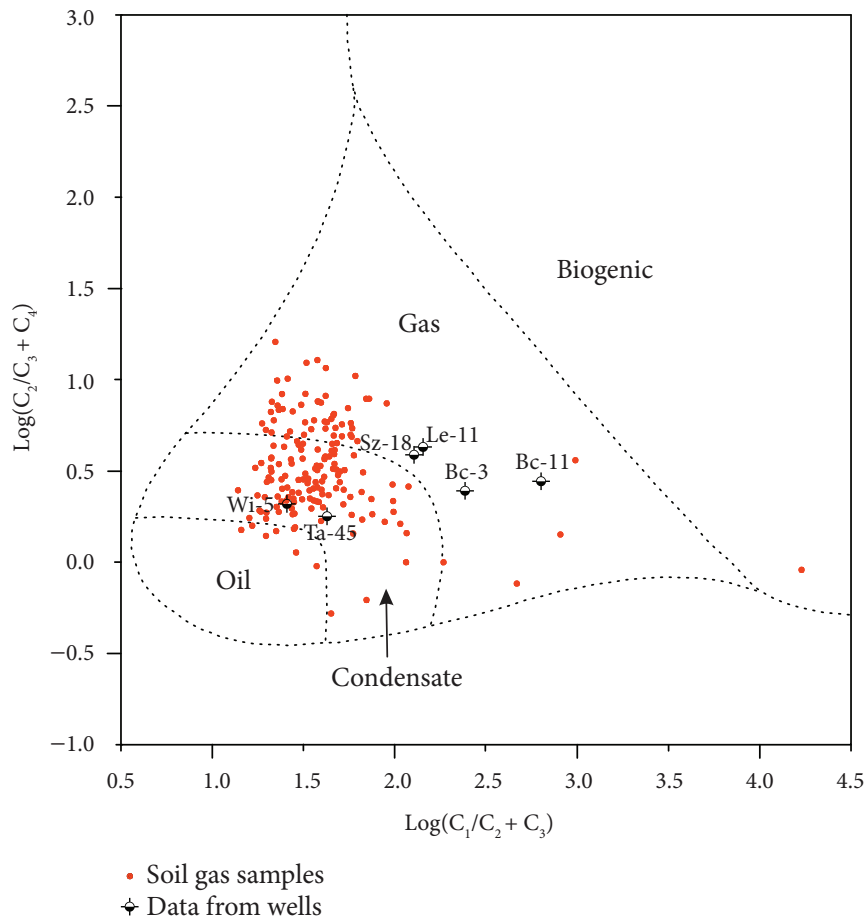

FiguRE 7: Composition cross-plot of soil gas samples (field boundaries after [51]).

variable character of hydrocarbon seepage, whereas the statistical parameters of the $\mathrm{C}_{2} / \mathrm{C}_{2}$ ratio evidence mainly moderate and active microseepage of alkanes from deep accumulations [12].
4.4. Surface Distribution of Alkane Anomalies and Hydrocarbon Shows during the Drilling and the Results of Well Testing. The distribution of concentrations of total alkanes $\mathrm{C}_{2}-\mathrm{C}_{5}$ reveals 13 surface anomalies of diverse ranges 


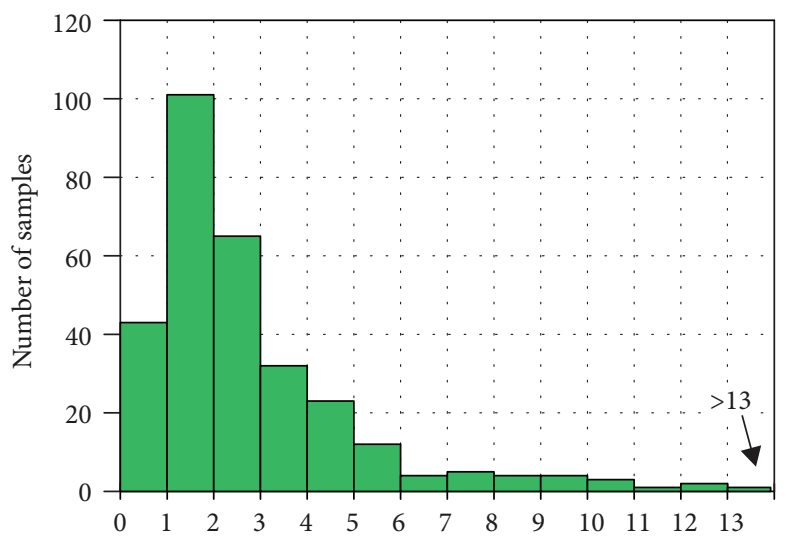

(a)

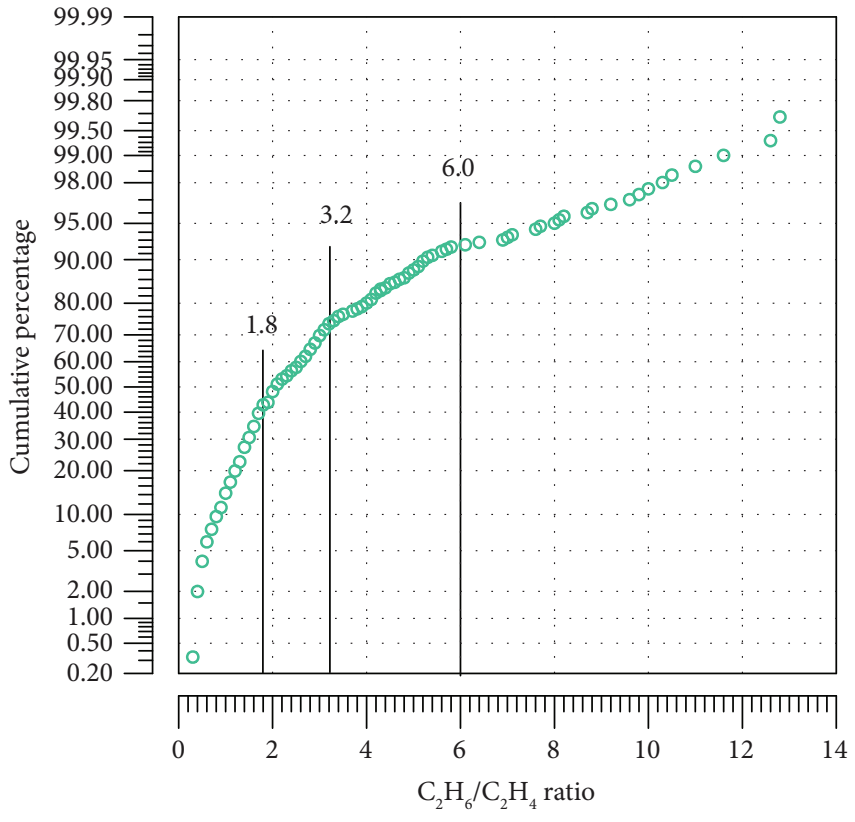

(b)

Figure 8: Histogram (a) and cumulative frequency diagram (b) of $\mathrm{C}_{2} / \mathrm{C}_{2}$ ratios calculated for analyzed soil gas components.

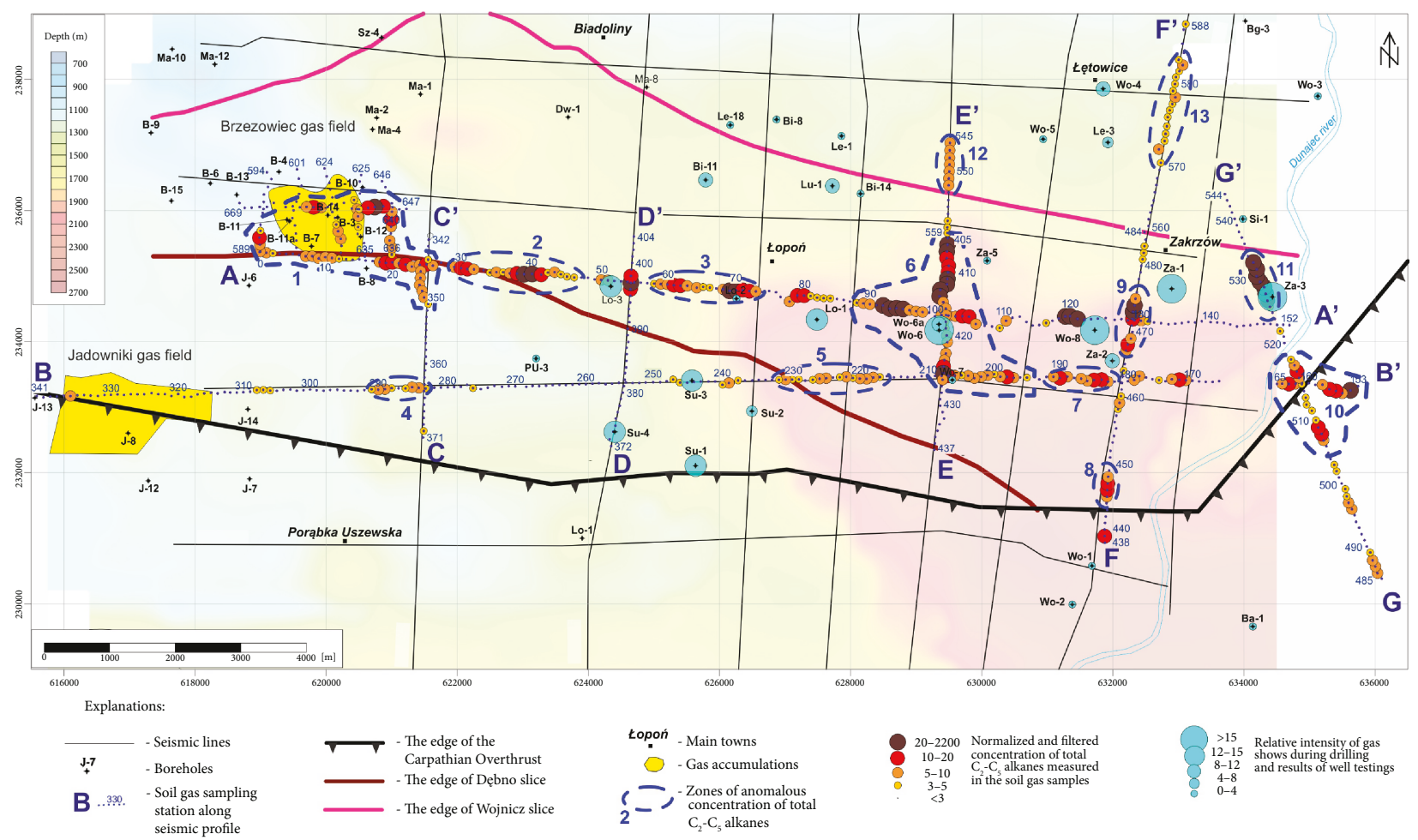

FIgURE 9: Spatial distribution of normalized concentrations of total alkanes $C_{2}-C_{5}$ superimposed on a structural map of the Miocene basement in the Brzesko-Wojnicz area.

(see Figure 9). The highest number of such anomalous concentrations occurs over the Wojnicz slice, particularly over the area of the so-called "Wojnicz Graben" where the bottom surface of the Miocene suite is much depressed (see Figure 9) and where the thickness of autochthonous Miocene formation increases (see Figure 10). Such distribution may suggest relatively high "hydrocarbon potential" of a part of this area [67]. The Wojnicz Graben is bordered on the south by the 


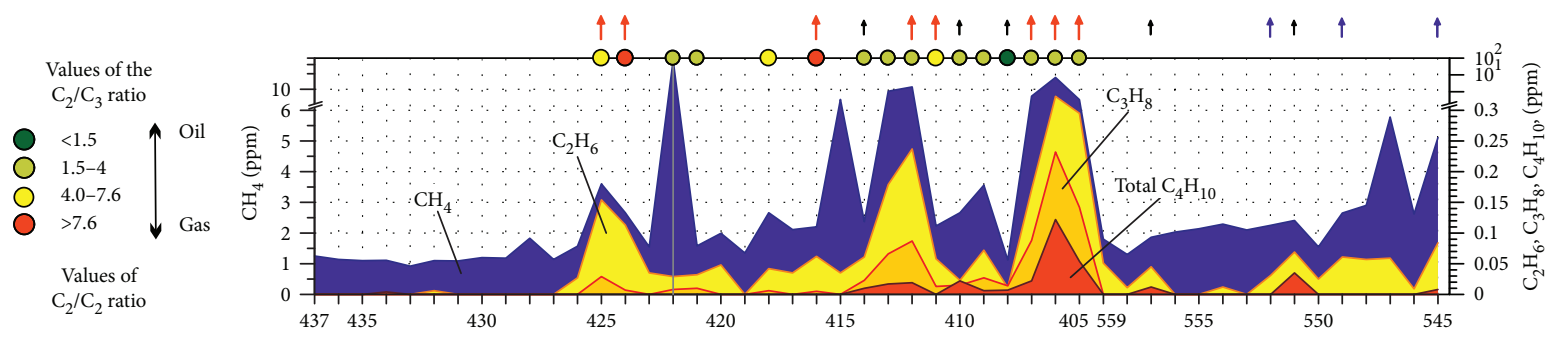

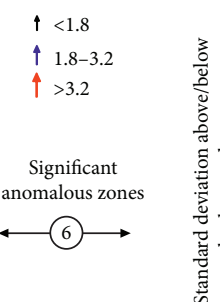

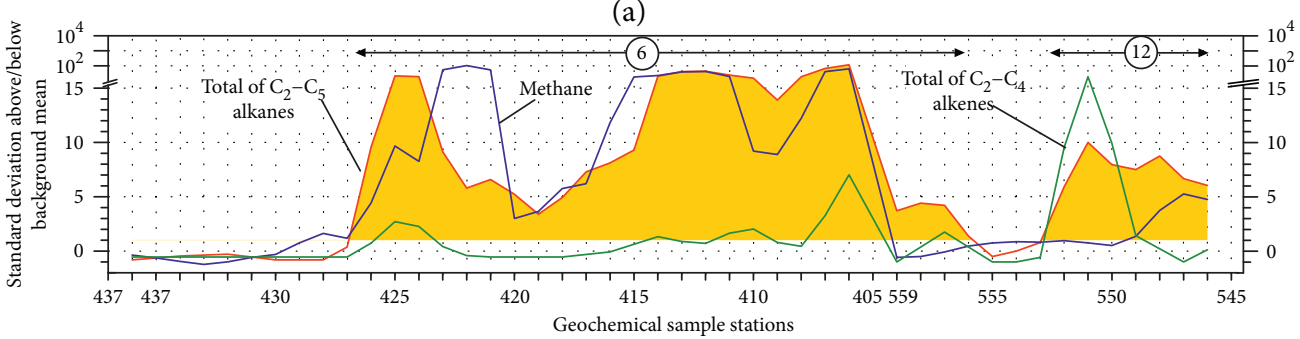

(b)

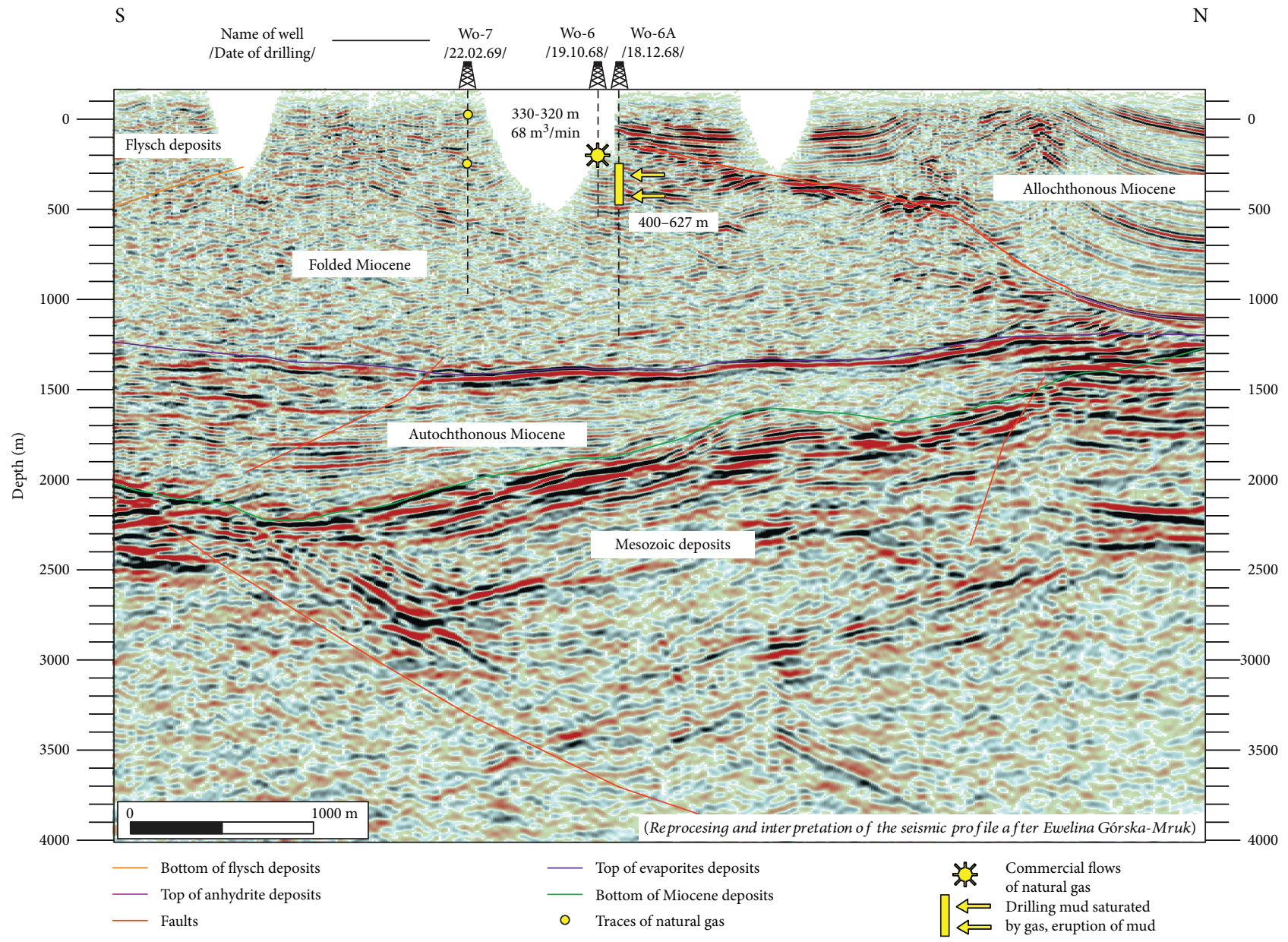

(c)

FIGURE 10: Variations in soil gas geochemistry along the E-E' seismic profile (see the location in Figures 1(b) and 9). (a) Graphs show variations in measured concentrations of alkanes as well as in $\mathrm{C}_{2} / \mathrm{C}_{3}$ ratios (coloured circles) and in $\mathrm{C}_{2} / \mathrm{C}_{2=}$ ratios (coloured arrows); (b) graphs show variations in normalized concentrations of total alkanes $C_{2}-C_{5}$, total alkenes $C_{2}-C_{4}$, and methane; (c) the interpreted seismic section along the $\mathrm{E}^{-} \mathrm{E}^{\prime}$ seismic line. 
Dębno slice over which the anomalous values of total alkanes $\mathrm{C}_{2}-\mathrm{C}_{5}$ vanish, as clearly demonstrated by the $\mathrm{B}-\mathrm{B}^{\prime}$ seismic section (see Figure 9). This may confirm the low "hydrocarbon potential" of strongly folded Miocene strata building the Dębno slice. Moreover, the lack of anomalies in that part of the study area may indicate that the thrust surface of the Dębno slice together with the marginal part of the Carpathian orogen pile forms a barrier for vertical migration and microseepage of hydrocarbons from deeper parts of the Miocene suite, from the basement as well as from the flysch formations. This concept is confirmed by the total absence of anomalies over the Jadowniki gas deposit located at the margin of the Carpathian Overthrust (see Figure 9).

The anomalies number 1 , number 2 , and number 5 are clearly related to the contour of the Dębno slice. Moreover, the eastern part of number 1 anomaly may be linked to the developed and currently exploited Brzezowiec gas deposit. Here, the anomalies may suggest the extension of that gas accumulation towards the southeast (see Figure 9). However, directly over the Brzezowiec deposit, the anomalies became much less visible, particularly in the vicinity of almost all exploration and production wells. The fading or even the vanishing of geochemical anomalies reflects the presence of a specific "depression cone" caused by long-term exploitation of that gas deposit. Such phenomena may result from the change of direction of hydrocarbon migration from vertical (i.e., natural in the rock formations) to horizontal, controlled by the effects of gas exploitation. Such modification of surface geochemical anomalies over producing hydrocarbon deposit was described by Tedesco [5].

Among the identified anomalies, the largest is the number 6 zone (see Figure 9), which may indicate the presence of gas accumulation at depth. Such a conclusion is supported by strong gas saturation of drilling mud and by gas eruptions, which occurred in 1968 during the drilling of Wo-6 and Wo$6 \mathrm{~A}$ wells. Moreover, after perforation of a depth interval of $330-320 \mathrm{~m}$ in the Wo-6 well, the gas inflow of $68 \mathrm{~m}^{3} / \mathrm{min}$ was obtained (see Table 2) from sandy mudstones [68]. Comparing the drilling data and the pattern of anomalies shown in the seismic section (see Figure 10), we conclude that there is recent, continuous microseepage of hydrocarbons from gas-saturated, folded, and autochthonous Miocene formations and from the basement. The latter is confirmed by diverse trends in compositions of alkane anomalies. The presence of heavier gaseous alkanes (butanes) in the northern part of number 6 anomaly (sampling sites numbers 405-414) (see Figure 10(a)) may point to hydrocarbon flux from deeper Miocene horizons and from the Mesozoic basement, which both contain a local anticline under this anomaly (Figure 10(c)).

The intensive hydrocarbon shows observed some decades ago during drilling at shallow depths together with currently identified strong geochemical anomalies (number 6 anomaly) may advocate the possible presence of shallow structural traps related to an anticline formed during the backward thrusting over the so-called "triangle zone", as suggested by Krzywiec et al. [28]. According to these authors, gas accumulations may occur also in stratigraphic traps related to pinchouts of subevaporite (Lower Badenian or older) and coarse-clastic sediments potentially filling the marginal zones of erosional valleys [28]. The existence of such accumulations is supported by geochemical anomalies including the higher gaseous alkanes (see Figure 10(a)), which might have been generated in deep-seated Miocene formations [19]. However, the presence of hybrid hydrocarbon accumulations of unconventional character cannot be neglected as well [21].

The total absence of hydrocarbon anomalies in the southern part of the E-E' seismic profile (see Figure 10(b)) can be an effect of an "isolation" caused by the Carpathian Overthrust and the adjacent Dębno slice. The intersection line of the latter can extend somewhat further to the north (see Figure 9). Another reason of this lack of anomalies in the southern part of this profile (see Figure 10(b)) can be the high-angle fault cutting through the autochthonous Miocene strata. Its surface may provide a barrier for hydrocarbons migrating from deep-seated autochthonous Miocene strata and/or from the basement (see Figure 10(c)).

The number 8 and 10 anomalies of alkane concentrations are linked to the marginal zone of the Carpathian Overthrust and may reflect the migration of gaseous hydrocarbons from deep-seated autochthonous Miocene strata and/or from the basement (see Figures 9 and 11). Particularly interesting is the number 10 anomaly located at the crossing of seismic sections (see Figure 9) because it suggests the presence of gas accumulation in Miocene strata sealed by the Carpathian Overthrust. Such accumulations are very common in the marginal zone of the Carpathian Fold-and-Thrust Belt [2, 3].

The number 7 and 9 anomalies surround the probable hydrocarbon accumulation encountered by the Wo- 8 well (see Figures 9 and 11). The gas inflow of $63 \mathrm{~m}^{3} / \mathrm{min}$ took place after perforation of a depth interval of $895-950 \mathrm{~m}$ (see Figure 11(c)). The coring of this interval found dark-grey, medium-grained clayey shale and mudstone as well as a claystone series interbedded with mudstones [68]. Moreover, a gas inflow of $23 \mathrm{~m}^{3} / \mathrm{min}$ was obtained from the $\mathrm{Za}-1$ well located northeast of the number 9 anomaly (see Figure 9). The inflow took place after perforation of a depth interval of 1210-1270 m, in which grey shales with low amount of sand fraction were identified. The results of both the Wo- 8 and Za-1 drillings demonstrate that not only can the sandstone horizons be gas-saturated, but Miocene shales and clayey mudstones may reveal high hydrocarbon potential as well.

In the northern part of the F-F' ${ }^{\prime}$ seismic profile, number 13, a low-intensity anomaly, was found (see Figures 9 and 11(b)), underlain by flat-lying allochthonous Miocene strata (see Figure 11(c)), which indicates relatively low hydrocarbon potential of this area.

The number 11 anomaly was localized in the neighbourhood of the interpreted boundary between the Wojnicz and the Biadoliny slices (see Figure 9). It may suggest the presence of shallow hydrocarbon accumulation in Miocene sediments sealed by the backward thrust of detached evaporites forming the bottom portions of both the Chodenice and the Grabowiec beds.

Our results demonstrate relatively high correlations between the distribution of surface geochemical anomalies 


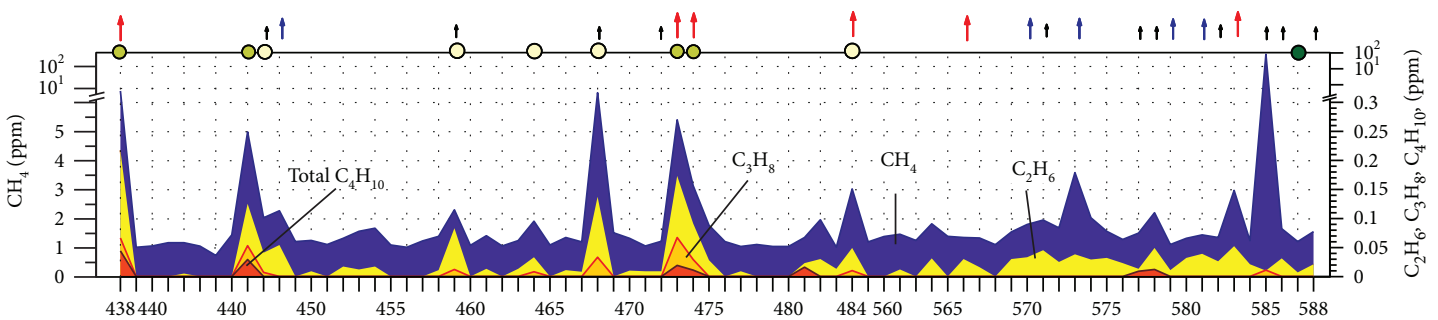

(a)

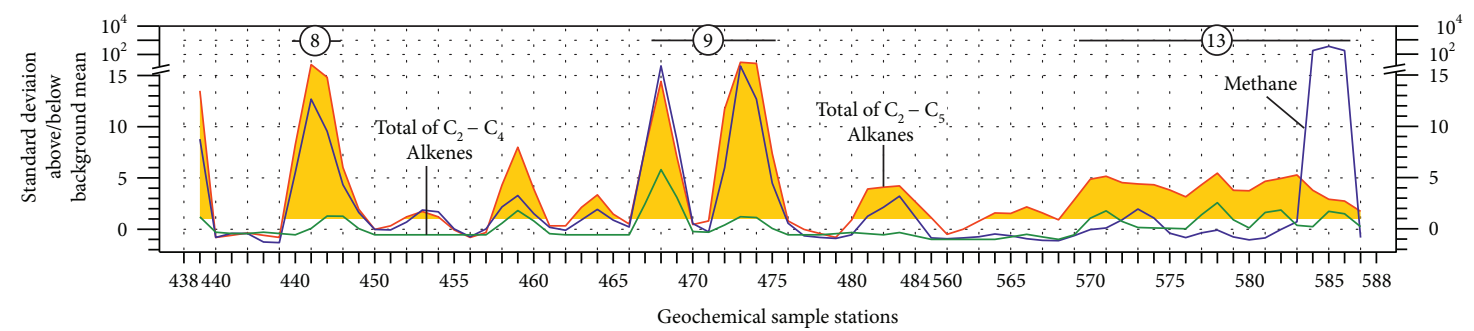

(b)

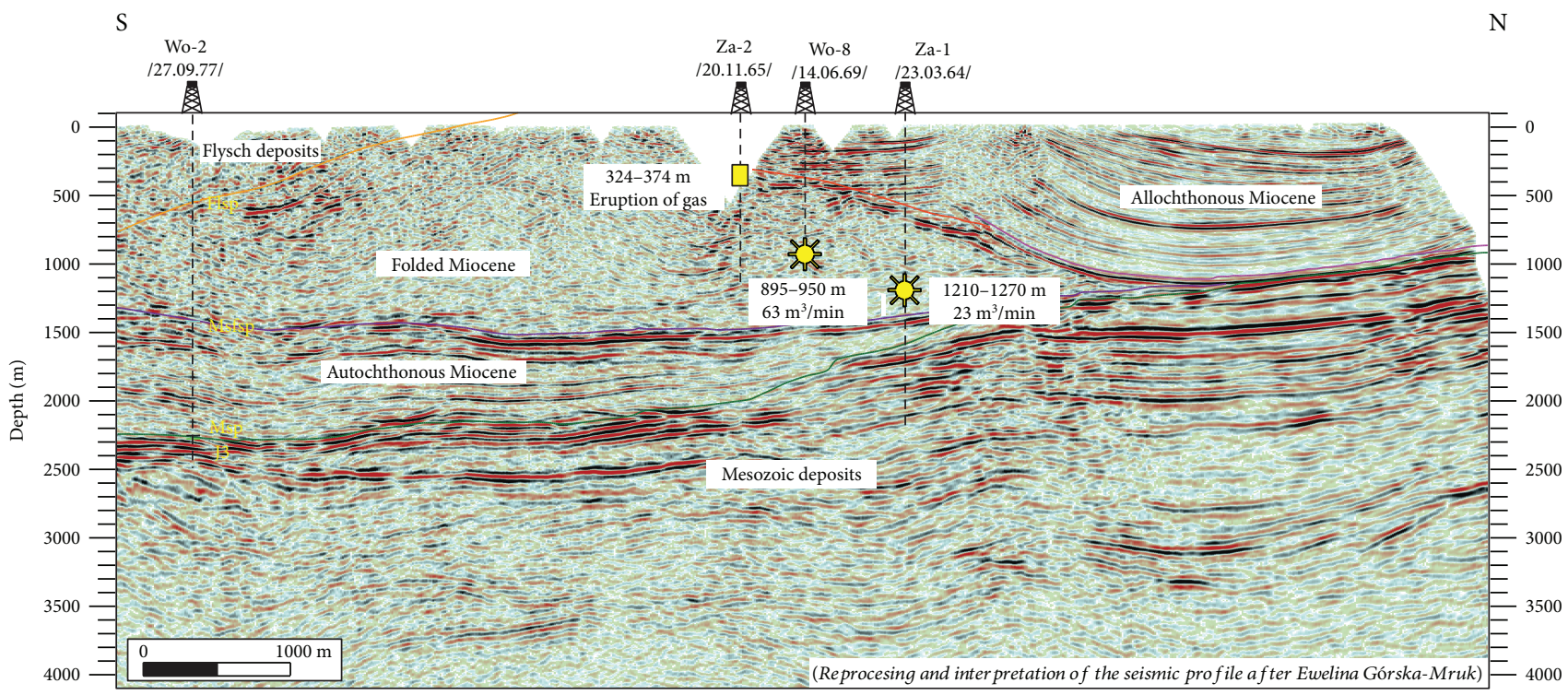

(c)

Figure 11: Variations of soil gas geochemistry along the F-F' seismic profile (see the location in Figures 1(b) and 9). For explanations, see Figure 10 .

and the relative intensity of hydrocarbon shows in the wells (see Figure 9). Especially interesting is the widespread number 6 anomaly of total alkanes $\mathrm{C}_{2}-\mathrm{C}_{5}$, which was identified over the central part of the Wojnicz Graben. It grades further to the east into the number 7 anomaly and then northward into the number 9 anomaly (see Figure 9). Within the range of these three anomalies, five wells are located: Wo-6, Wo-6A, Wo-8, Za-1, and $\mathrm{Za}-2$, all completed in the years 1964-69. In these wells, both the gas explosions and the strong mud eruptions took place during the drilling operations together with commercial gas inflows from Miocene mudstone-claystone horizons (see Table 2). Also interesting is the number 11 anomaly located in the G-G' seismic profile adjacent to the $\mathrm{Za}-3$ well and also to the $\mathrm{Si}-1$ well, which lacks an anomaly in its vicinity (see Figure 9). It must be noticed that in the Za-3 well (completed in 1965), strong gas and brine inflow was obtained from $555 \mathrm{~m}$ depth during withdrawal of the drill bit. After perforation at a depth interval of about $1036-1243 \mathrm{~m}$, a gas inflow of almost $15 \mathrm{~m}^{3} / \mathrm{min}$ was obtained (see Table 2). During the drilling of the Si-1 well in 1963, only small traces of gas in the drilling mud were observed (see Table 2). A comparison of the results of these two drillings located almost exactly at the line of soil gas sampling stations demonstrates a distinct link of hydrocarbon shows noticed during the drilling operations with the recent microseepage of alkanes. Hence, it may confirm a high "hydrocarbon potential" of the Wojnicz Graben, and, simultaneously, it provides evidence of the applicability of geochemical methods in the localization of such prospective zones. 


\section{Conclusions}

A surface geochemical survey was carried out in the Carpathian Foredeep, in the area between Brzesko and Wojnicz towns, over the contact zone with the Carpathian Fold-and-Thrust Belt (Southeastern Poland). In this area, two gas deposits have been discovered to the present: Brzezowiec and Jadowniki. In the first deposit, gas is reservoired within the Miocene and the Cenomanian strata, and in the second, it is hosted within the Lower Badenian rocks.

The surface geochemical survey provided a total number of 670 soil gas samples collected from $1.2 \mathrm{~m}$ depth and analyzed with the gas chromatography. The sampling stations were positioned along 7 seismic profiles and along 6 short sampling lines located over the Brzezowiec gas deposit. Maximum detected concentrations of methane, total alkanes $\mathrm{C}_{2}-\mathrm{C}_{5}$, and total alkenes $\mathrm{C}_{2}-\mathrm{C}_{4}$ were $271000 \mathrm{ppm}$ (27.1 vol.\%), $45.3 \mathrm{ppm}$, and $0.49 \mathrm{ppm}$, respectively. Maximum concentrations of $\mathrm{H}_{2}$ and $\mathrm{CO}_{2}$ reached 0.232 and 6.29 vol.\%, respectively, and show only a weak correlation with concentrations of total alkanes $\mathrm{C}_{2}-\mathrm{C}_{5}$, the latter being the most useful hydrocarbon exploration geochemical parameter. The range of concentrations and the mean value of oxygen were $6-20$ vol. $\%$ and 18.2 vol.\%, respectively. Moreover, we did not find correlation between oxygen and hydrocarbon concentrations; also, we observed only weak negative correlation between oxygen and carbon dioxide values. Statistical analysis of the results allowed us to identify anomalies of total alkanes $\mathrm{C}_{2}-\mathrm{C}_{5}$ in the study area. The results of this surface geochemical survey were integrated with seismic cross sections and supplemented by production data from particular wells. The following conclusions are presented for the study area:

(a) The alkane anomalies originated from hydrocarbon migration from subsurface hydrocarbon sources. Light gaseous alkanes (methane, ethane) mostly migrated from relatively shallow Miocene strata whereas the higher gaseous hydrocarbons ascended from deeper Miocene formations as well as from the Paleozoic-Mesozoic basement. The high methane concentrations detected in some soil gas were presumably generated by recent biochemical processes operating in the near-surface zone.

(b) The ethane/propane ratios indicated that alkanes detected in the near-surface zone ascended by microseepage from a few predominantly gas and gas condensate accumulations of diverse compositions.

(c) The results allowed us to identify 13 anomalies of concentrations of total alkanes $\mathrm{C}_{2}-\mathrm{C}_{5}$ ranging in size from 500 to $1500 \mathrm{~m}$, which point out to the presence of conventional hydrocarbon accumulations and/or to the existence of gas-saturated mudstone and heterolithic successions. The distribution of these anomalies is controlled by the intersection lines of both the Dębno and the Wojnicz slice-folds. (d) Most of the surface geochemical anomalies were found over the Wojnicz Trough, suggesting a high petroleum potential for this structure.

(e) Insignificant anomalies localized directly over the Brzezowiec gas deposit resulted from its long-term exploitation whereas the anomalies identified southeast of the deposit contour suggest the extension of this gas accumulation in that direction.

(f) The lack of surface geochemical anomalies over the Jadowniki gas deposit is an effect of the regionally extended Carpathian Overthrust and adjacent Dębno slice, whose surfaces provide a barrier for vertical microseepage of hydrocarbons.

(g) Our results revealed relatively high correlation between the distribution of surface geochemical anomalies and the relative intensity of hydrocarbon shows recorded in the wells. It is valid for anomalies located over the central part of the Wojnicz Graben and in the vicinity of Wo-6, Wo-6A, Wo-8, $\mathrm{Za}-1$, and $\mathrm{Za}-2$ wells completed in the years 1964-69, in which gas explosions and strong drilling mud eruptions together with commercial gas inflows from Miocene shale and mudstoneclaystone formations were encountered during the drilling operations.

The integrated results of surface geochemical and seismic surveys referring to the regularities in distribution of anomalous phenomena during the drilling operations have enabled us to select the zones' optimal "hydrocarbon potential" in the Brzesko-Wojnicz area. We expect that these results will allow the geologists to identify probable but yet undiscovered hydrocarbon accumulations together with presumed unconventional hydrocarbon reservoirs.

\section{Conflicts of Interest}

The authors declare that there is no conflict of interest regarding the publication of this paper.

\section{Acknowledgments}

The authors are very much grateful to the Polish Oil and Gas Company in Warsaw for providing the seismic and the well data. The authors are grateful to anonymous reviewers for the comments and valuable suggestions. The research was funded as a part of the "Blue Gas" Project of the National Centre for Research and Development (Grant no. BG2/ShaleFore/14).

\section{References}

[1] Mineral Resources of Poland. Polish Geological Institute National Research Institute, "Natural gas," January 2018, http://geoportal.pgi.gov.pl/surowce/energetyczne/gaz_ziemny/ 2016.

[2] M. Myśliwiec, "Miocene reservoir rocks in the Carpathian Foredeep," Przeglad Geologiczny, vol. 52, pp. 581-592, 2004. 
[3] M. Myśliwiec, Z. Borys, B. Bosak et al., "Hydrocarbon resources of the Polish Carpathian Foredeep: reservoirs, traps, and selected hydrocarbon fields," in The Carpathians and Their Foreland: Geology and Hydrocarbon, AAPG Memoir 84, J. Golonka and F. J. Picha, Eds., pp. 351-393, 2006.

[4] R. W. Klusman, Soil Gas and Related Methods for Natural Resource Exploration, John Wiley \& Sons Ltd., Chichester, UK, 1993.

[5] S. A. Tedesco, Surface Geochemistry in Petroleum Exploration, Chapman \& Hall Int. Thomson Publ. Co., New York, NY, USA, 1995.

[6] M. D. Matthews, "Migration - a view from the top," in Hydrocarbon Migration and Its Near-Surface Expression: AAPG Memoir 66, D. Schumacher and M. A. Abrams, Eds., pp. 139-155, Texaco International Exploration Division, Bellaire, TX, USA, 1996.

[7] D. Schumacher, "Surface geochemical exploration for oil and gas: new life for an older technology," The Leading Edge, vol. 19, no. 3, pp. 258-261, 2000.

[8] R. MacElvain, "Mechanics of gaseous ascension through sedimentary column," in Unconventional Methods in Exploration for Petroleum and Natural Gas, Symposium 1, W. B. Heroy, Ed., pp. 15-28, Southern Methodist University Press, Dallas, TX, USA, 1969.

[9] L. C. Price, "A critical overview and proposed working model of surface geochemical exploration," in Unconventional Methods in Exploration for Petroleum and Natural Gas IV, M. J. Davidson, Ed., pp. 245-304, Southern Methodist University Press, Dallas, TX, USA, 1986.

[10] G. K. Arp, "Effusive microseepage: a first approximation model for light hydrocarbons movement in the subsurface," Association of Petroleum Geochemical Explorationists Bulletin, vol. 8, pp. 1-17, 1992.

[11] V. T. Jones and S. G. Burtell, "Hydrocarbon flux variations in natural and anthropogenic seeps," in Hydrocarbon Migration and Its Near-Surface Expression: AAPG Memoir 66, D. Schumacher and M. A. Abrams, Eds., pp. 203-221, Exploration Technologies, Inc., Houston, TX, USA, 1996.

[12] D. F. Saunders, K. R. Burson, and C. K. Thompson, "Model for hydrocarbon microseepage and related near-surface alterations," AAPG Bulletin, vol. 83, pp. 170-184, 1999.

[13] P. Marzec, H. Sechman, M. Kasperska et al., "Onshore gas chimney in light of seismic and geochemical evidence, Carpathian Foredeep (Miocene, SE Poland)," Basin Research, vol. 30, Supplement 1, pp. 210-227, 2018.

[14] S. J. Porębski, K. Pietsch, R. Hodiak, and R. J. Steel, "Origin and sequential development of Upper Badenian-Sarmatian clinoforms in the Carpathian Foredeep Basin, SE Poland," Geologica Carpathica, vol. 54, pp. 119-136, 2002.

[15] M. Paszkowski, S. J. Porębski, and M. Warchoł, "Koncepcja projektu otworu kierunkowego w mioceńskich utworach zapadliska przedkarpackiego," Wiadomości Naftowe i Gazownicze, vol. 131, no. 3, pp. 4-13, 2009.

[16] P. Lis and A. Wysocka, "Middle Miocene deposits in Carpathian Foredeep: facies analysis and implications for hydrocarbon reservoir prospecting," Annales Societatis Geologorum Poloniae, vol. 82, pp. 239-253, 2012.

[17] M. J. Kotarba and T. M. Peryt, "Geology and petroleum geochemistry of Miocene strata in the Polish and Ukrainian Carpathian Foredeep and its Palaeozoic-Mesozoic basement," Annales Societatis Geologorum Poloniae, vol. 81, pp. 211-220, 2011.

[18] M. J. Kotarba, "Origin of natural gases in the autochthonous Miocene strata of the Polish Carpathian Foredeep," Annales Societatis Geologorum Poloniae, vol. 81, pp. 409-424, 2011.

[19] M. J. Kotarba, D. Więcław, P. Kosakowski, and A. Kowalski, "Hydrocarbon potential of source rocks and origin of natural gases accumulated in Miocene strata of the Carpathian Foredeep in Rzeszów area," Przegląd Geologiczny, vol. 53, pp. 67-76, 2005.

[20] J. M. Hunt, Petroleum Geochemistry and Geology, Freeman and Co., New York, NY, USA, 1996.

[21] T. Kozimor, J. Potera, and M. Nieć, "Hybrid hydrocarbon accumulations (conventional accompanied by unconventional ones) and reporting of their resources," Przeglad Geologiczny, vol. 65, pp. 643-649, 2017.

[22] S. Wdowiarz, "O stosunku Karpat do zapadliska przedkarpackiego w Polsce," Przegląd Geologiczny, vol. 24, pp. 350357, 1976.

[23] N. Oszczypko and A. Tomaś, "Tectonic evolution of marginal part of the Polish Flysch Carpathians in the Middle Miocene," Kwartalnik Geologiczny, vol. 29, pp. 109-128, 1985.

[24] N. Oszczypko, "The structural position and tectonosedimentary evolution of the polish outer Carpathians," Przeglad Geologiczny, vol. 52, pp. 780-791, 2004.

[25] N. Oszczypko, "Powstanie i rozwój polskiej części zapadliska przedkarpackiego," Przegląd Geologiczny, vol. 54, pp. 396403, 2006.

[26] R. Ney, W. Burzewski, T. Bachleda, W. Górecki, K. Jakóbczak, and K. Słupczyński, "Zarys paleogeografii i rozwoju litologiczno-facjalnego utworów miocenu zapadliska przedkarpackiego," Prace Geologiczne PAN, vol. 82, pp. 1-65, 1974.

[27] N. Oszczypko and A. Ślączka, "An attempt to palinspastic reconstruction of Neogene basins in the Carpathian Foredeep," Annales Societatis Geologorum Poloniae, vol. 55, pp. 55-76, 1985.

[28] P. Krzywiec, P. Aleksandrowski, R. Florek, and J. Siupik, "The structure of the Outer Carpathian orogenic front: an example of the Miocene Zgłobice Unit between Brzesko and Wojnicz (SE Poland)-new data, new models, new questions," Przeglad Geologiczny, vol. 52, pp. 1051-1059, 2004.

[29] K. Sowiżdżał, T. Słoczyński, I. Matyasik, and M. Stadtmüller, "Analiza paleozoicznego systemu naftowego w strefie brzeżnej nasunięcia Karpat fliszowych,” Nafta-Gaz, vol. 9, pp. 632-646, 2015.

[30] N. Oszczypko, P. Krzywiec, I. Papadyuk, and T. Peryt, "Carpathian Foredeep Basin (Poland and Ukraine): its sedimentary, structural, and geodynamic evolution," in The Carpathians and Their Foreland: Geology and Hydrocarbon Resources. AAPG Memoir 84, J. Golonka and F. J. Picha, Eds., pp. 293-350, The American Association of Petroleum Geologists, 2006.

[31] Z. Kirchner and S. Połtowicz, "Budowa geologiczna obszaru między Brzeskiem a Wojniczem," Rocznik Polskiego Towarzystwa Geologicznego, vol. 44, pp. 293-320, 1974.

[32] N. Oszczypko, "Mioceńska dynamika polskiej części zapadliska przedkarpackiego," Przegląd Geologiczny, vol. 44, pp. 1007-1018, 1996. 
[33] N. Oszczypko, “The Western Carpathian Foredeepdevelopment of the foreland basin in front of the accretionary wedge and its burial history (Poland)," Geologica Carpathica, vol. 49, pp. 415-431, 1998.

[34] E. Jawor, "Utwory miocenu między Krakowem a Dębicą," Przeglad Geologiczny, vol. 31, pp. 635-641, 1983.

[35] N. Oszczypko, "The Miocene development of the Polish Carpathian Foredeep," Przeglad Geologiczny, vol. 49, pp. 717-723, 2001.

[36] S. Porębski and N. Oszczypko, "Lithofacies and origin of the Bogucice Sands (Upper Badenian), Carpathian Foredeep, Poland," Prace Państwowego Instytutu Geologicznego, vol. 168, pp. 57-82, 1999.

[37] P. Karnkowski, Oil and Gas Deposits in Poland, The Geosynoptics Society "GEOS" - University of Mining and Metallurgy, Krakow, 1999.

[38] M. J. Kotarba, "Origin of natural gases in the PaleozoicMesozoic basement of the Polish Carpathian Foredeep," Geologica Carpathica, vol. 63, pp. 307-318, 2012.

[39] P. Kosakowski, D. Więcław, M. Kotarba, and A. Kowalski, "Habitat and hydrocarbon potential of the Mesozoic strata in the Kraków - Rzeszów area (SE Poland)," Geological Quarterly, vol. 56, pp. 139-152, 2012.

[40] H. Sechman, M. Dzieniewicz, and A. Nowicka, "Light hydrocarbons in soil gas above prospective oil- and gasbearing structures: Pomeranian Synclinorium, NW Poland," Journal of Petroleum Geology, vol. 34, no. 4, pp. 365-385, 2011.

[41] H. Sechman, M. Dzieniewicz, and B. Liszka, "Soil gas composition above gas deposits and perspective structures of the Carpathian Foredeep, SE Poland," Applied Geochemistry, vol. 27, no. 1, pp. 197-210, 2012.

[42] H. Sechman, "Detailed compositional analysis of hydrocarbons in soil gases above multi-horizon petroleum deposits - a case study from Western Poland," Applied Geochemistry, vol. 27, no. 10, pp. 2130-2147, 2012.

[43] H. Sechman, W. J. Mościcki, and M. Dzieniewicz, "Pollution of near-surface zone in the vicinity of gas wells," Geoderma, vol. 197-198, pp. 193-204, 2013.

[44] H. Sechman and M. Dzieniewicz, "The example of background determination and mathematical processing of data from surface geochemical survey for the purposes of petroleum exploration," Journal of Petroleum Science and Engineering, vol. 78, no. 2, pp. 396-406, 2011.

[45] R. W. Klusman, "Interpretation and display of surface geochemical data," Surface Exploration Case Histories, AAPG Studies in Geology 48, D. Schumacher and L. A. LeSchack, Eds., pp. 1-24, The American Association of Petroleum Geologists, 2002.

[46] H. Sechman and M. Dzieniewicz, "Influence of soil moisture on the results of surface geochemical survey applied to petroleum exploration," Journal of Petroleum Science and Engineering, vol. 56, no. 4, pp. 267-282, 2007.

[47] V. T. Jones and R. J. Drozd, "Prediction of oil or gas potential by near-surface geochemistry," AAPG Bulletin, vol. 67, pp. 932-952, 1983.

[48] D. F. Saunders, K. R. Burson, and C. K. Thompson, "Observed relation of soil magnetic susceptibility and soil gas hydrocarbon analyses to subsurface hydrocarbon accumulations," AAPG Bulletin, vol. 75, pp. 389-408, 1991.
[49] D. F. Saunders, K. R. Burson, J. J. Brown, and C. K. Thompson, "Combined geological and surface geochemical methods discovered Agaritta and Brady Creek fields, Concho County, Texas," AAPG Bulletin, vol. 77, pp. 1219-1240, 1993.

[50] H. Sechman, G. Izydor, P. Guzy, and M. Dzieniewicz, "Surface geochemical exploration for hydrocarbons in the area of prospective structures of the Lublin Trough (Eastern Poland)," Marine and Petroleum Geology, vol. 61, pp. 22-38, 2015.

[51] V. T. Jones, M. D. Matthews, and D. M. Richers, "Chapter 5 light hydrocarbons for petroleum and gas prospecting," Handbook of Exploration Geochemistry, vol. 7, pp. 133-212, 2000.

[52] J. B. Davis and R. M. Squires, "Detection of microbially produced gaseous hydrocarbons other than methane," Science, vol. 119, no. 3090, pp. 381-382, 1954.

[53] M. J. Gole and C. R. M. Butt, "Biogenic-thermogenic nearsurface gas anomaly over Gingin and Bootine gas fields, Western Australia," AAPG Bulletin, vol. 69, pp. 2110-2119, 1985.

[54] R. W. Klusman, "Transport of ultratrace reduced gases and particulate, near-surface oxidation, metal deposition and adsorption," Geochemistry: Exploration, Environment Analysis, vol. 9, no. 3, pp. 203-213, 2009.

[55] R. W. Klusman, "Comparison of surface and near-surface geochemical methods for detection of gas microseepage from carbon dioxide sequestration," International Journal of Greenhouse Gas Control, vol. 5, no. 6, pp. 1369-1392, 2011.

[56] R. W. Klusman, "Detailed compositional analysis of gas seepage at the National Carbon Storage Test Site, Teapot Dome, Wyoming, USA," Applied Geochemistry, vol. 21, no. 9, pp. 1498-1521, 2006.

[57] W. Harbert, V. T. Jones, J. Izzo, and T. H. Anderson, “Analysis of light hydrocarbons in soil gases, Lost River region, West Virginia: relation to stratigraphy and geological structures," AAPG Bulletin, vol. 90, no. 5, pp. 715-734, 2006.

[58] H. Sechman, J. Kuśmierek, G. Machowski, P. Guzy, and M. Dzieniewicz, "Surface geochemical anomalies in the vicinity of the Wańkowa oil field (SE Polish Carpathians)," Annales Societatis Geologorum Poloniae, vol. 86, pp. 219-235, 2016.

[59] R. J. Pallasser, "Recognizing biodegradation in gas/oil accumulations through the $\delta^{13} \mathrm{C}$ compositions of gas components," Organic Geochemistry, vol. 31, no. 12, pp. 1363$1373,2000$.

[60] I. M. Head, D. M. Jones, and S. R. Larter, "Biological activity in the deep subsurface and the origin of heavy oil," Nature, vol. 426, no. 6964, pp. 344-352, 2003.

[61] J. Dolfing, S. R. Larter, and I. M. Head, "Thermodynamic constraints on methanogenic crude oil biodegradation," The ISME Journal, vol. 2, no. 4, pp. 442-452, 2008.

[62] V. Savary and M. Pagel, "The effects of water radiolysis on local redox conditions in the Oklo, Gabon, natural fission reactors 10 and 16," Geochimica et Cosmochimica Acta, vol. 61, no. 21, pp. 4479-4494, 1997.

[63] V. F. Nikonov, "Distribution of methane homologs in gas and oil fields," Akademia Nauk SSSR, Doklady, vol. 206, pp. 234-246, 1971.

[64] R. W. Klusman and M. A. Saeed, "Comparison of light hydrocarbon microseepage mechanisms," Hydrocarbon Migration and Its Near-Surface Expression, AAPG Memoir 66, D. Schumacher and M. A. Abrams, Eds., pp. 157-168, The American Association of Petroleum Geologists, 1996. 
[65] D. Leythaeuser, R. G. Schaefer, and H. Pooch, "Diffusion of light hydrocarbons in subsurface sedimentary rocks," $A A P G$ Bulletin, vol. 67, pp. 889-895, 1983.

[66] B. M. Krooss and D. Leythaeuser, "Molecular diffusion of light hydrocarbons in sedimentary rocks and its role in migration and dissipation of natural gas," Hydrocarbon Migration and Its Near-surface Expression. AAPG Memoir, 66, D. Schumacher and M. Abrams, Eds., pp. 173-185, The American Association of Petroleum Geologists, 1996.

[67] A. Góra, P. Guzy, A. Twaróg, E. Górska-Mruk, and H. Sechman, "Distributions of light hydrocarbons in the near surface zone of the marginal part of the Carpathian Foredeep and Outer Carpathians - case study from SE Poland," in 17th International Multidisciplinary Scientific GeoConference SGEM2017, Science and Technologies in Geology, Exploration and Mining, pp. 601-608, Albena, Bulgaria, September 2017.

[68] Polish Geological Institute - National Research Institute, "Boreholes in Central Geological Database (CBDG)," January 2018, http://geoportal.pgi.gov.pl/otwory. 

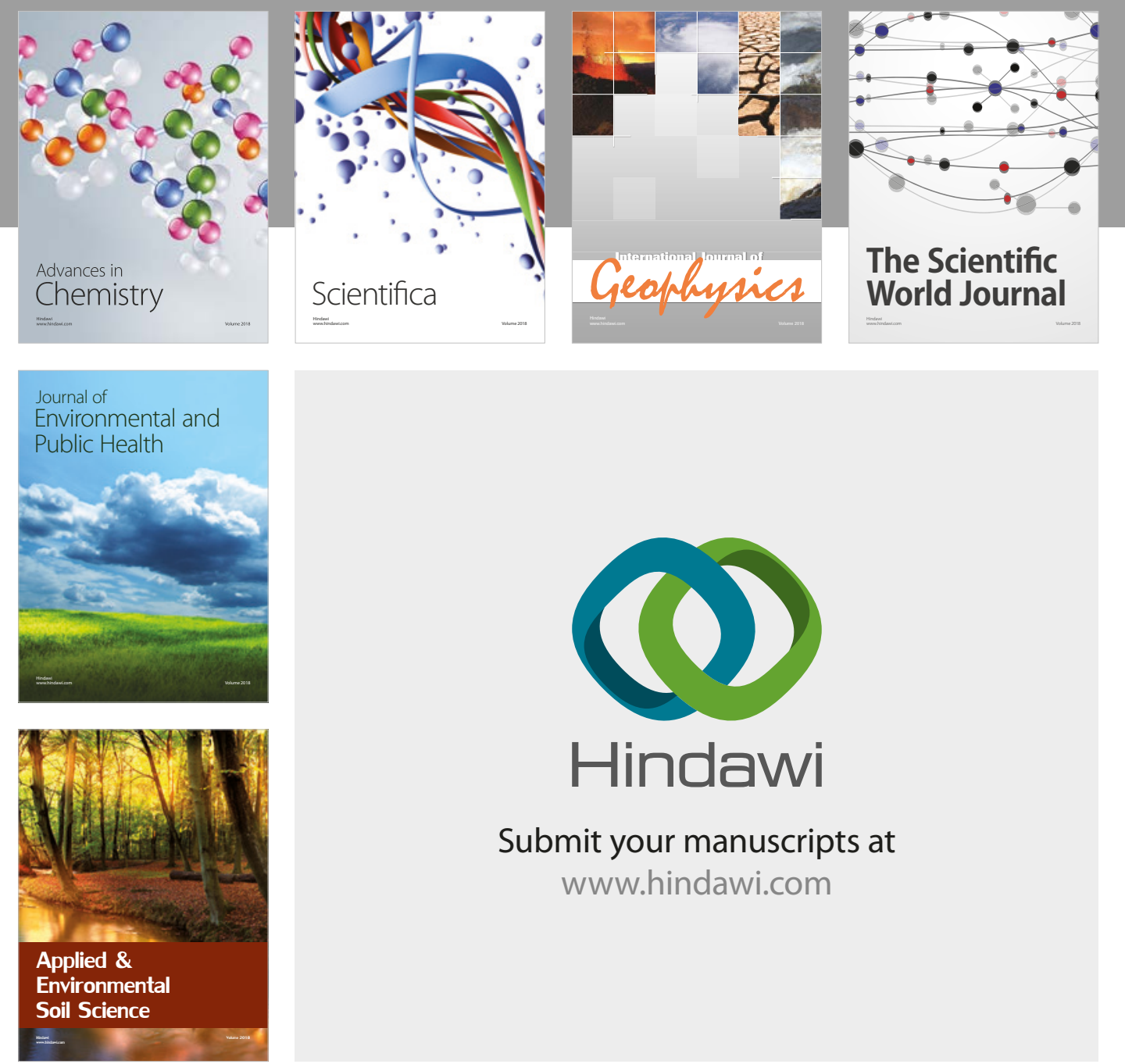

The Scientific

\section{World Journal}
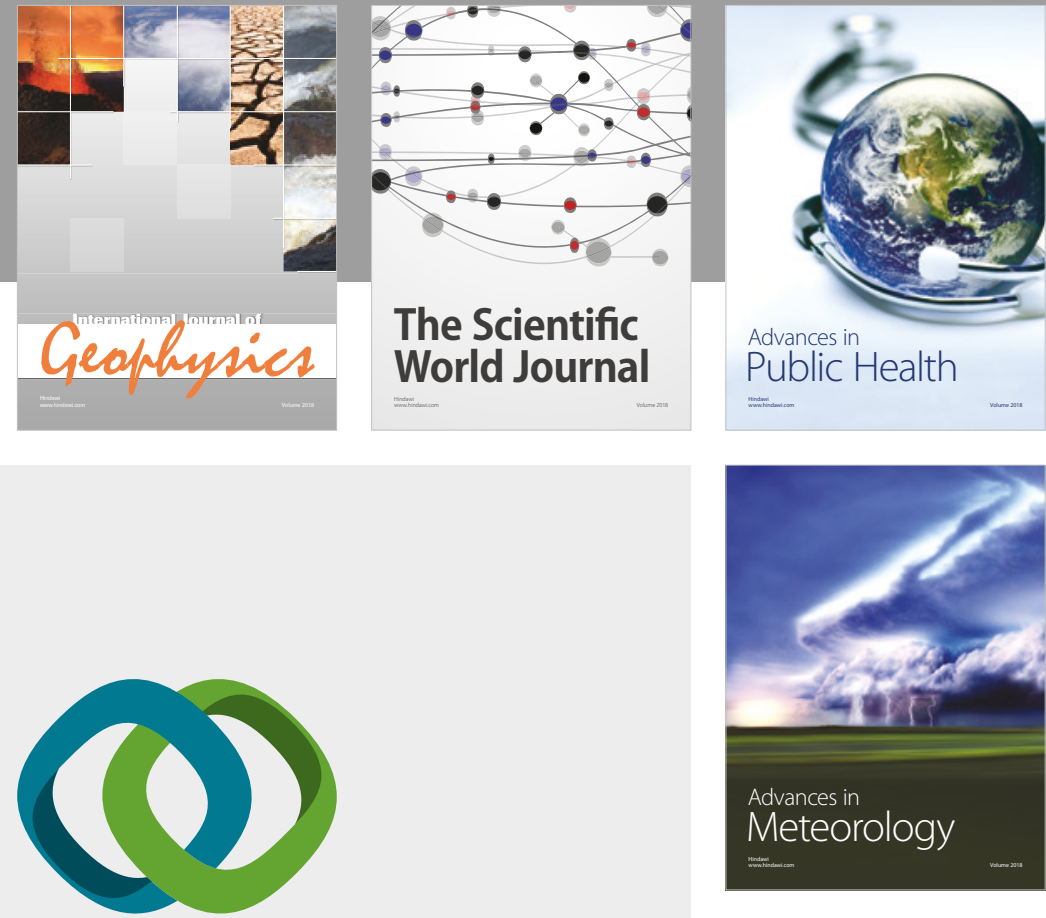

Advan

Public Health

\section{Hindawi}

Submit your manuscripts at

www.hindawi.com
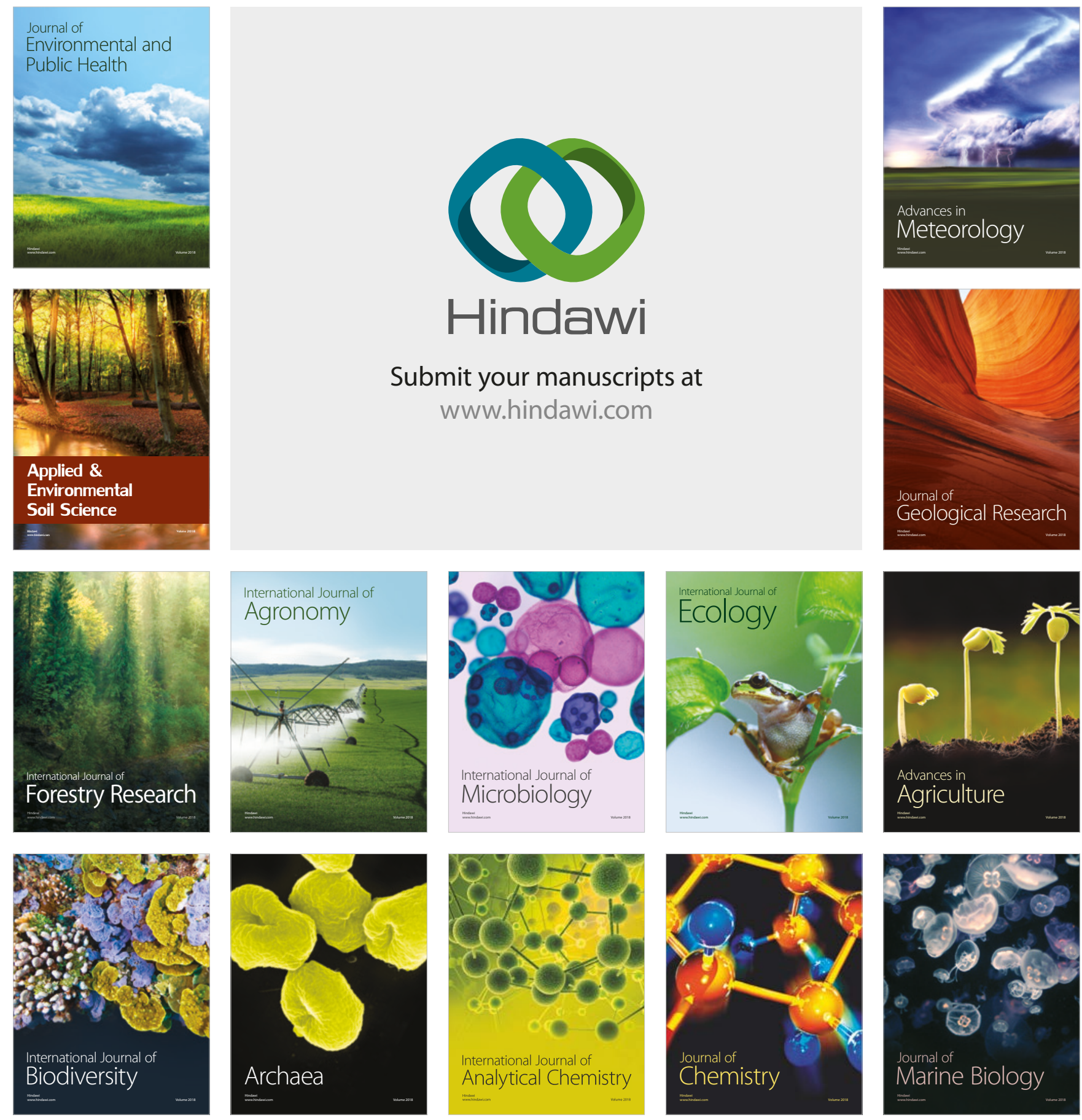